FINDING LIBERTY'S REFUGE:

\title{
BALANCING THE STATES AND THE INDIVIDUAL ON THE O'CONNOR COURT
}

\author{
A THESIS SUBMITTED \\ TO THE GRADUATE SCHOOL \\ IN PARTIAL FULFILLMENT OF \\ THE REQUIREMENTS FOR THE DEGREE OF \\ MASTER OF ARTS IN POLITICAL SCIENCE \\ BY \\ ERIC VAN DER VORT \\ (DR. SALLY JO VASICKO, CHAIR) \\ BALL STATE UNIVERSITY \\ MUNCIE, INDIANA \\ MAY 2011
}


I. Introduction

II. Constitutionalism, Federalism, and Expressive Democracy
a. Constitutionalism
b. Federalism
c. Expressive Democracy

i. Expressive Democracy and Federalism

III. Justice O'Connor and Federalism

a. O'Connor's Early Life

b. O'Connor's Professional Life

c. O'Connor's Federalism in Practice

IV. The State and the Individual

a. The First Amendment's Expression Protections

i. Cases Decided Against the State

ii. Cases Decided in Favor of the State

b. The First Amendment's Religious Protections

i. Cases Decided Against the State

ii. Cases Decided in Favor of the State

c. The Right to Privacy

i. Reproductive Freedoms

ii. Sexual Freedoms

V. Analysis

a. Wechsler's Neutral Principles

b. Ely's Theory of Judicial Review

VI. Conclusion 
To my “Gma”, Eileen Kelly Pingle.

$$
1930-2010
$$

"And ever has it been known that love knows not its own depth until the hour of separation." - Khalil Gibran, The Prophet 


\section{Acknowledgments}

A thesis is not an individual work. Rather, it is the result of the support and interaction of many, a genuine meeting of the minds that demands gratitude and requires acknowledgement. I would like to thank Dr. Sally Jo Vasicko of Ball State University for her guidance and support of this project. I am also indebted to Dr. Darren Wheeler and Dr. Misa Nishikawa, also of Ball State University, for their steadfast support over the past two years. I am most especially grateful to Dr. Sarah Combellick-Bidney of Augsburg College for her wit, wisdom, and her unflagging belief that my voice is worth using. To David Strife, Derek Worch, and Josh Thompson: thank you for being yourselves. Finally, to my mother Alberta, father Michael, brother Bryan, sisterin-law Nicole, and beautiful nieces Avery and Sydney, thank you for everything. 


\begin{abstract}
This paper examines the tension between states' rights and rights of the individual in the jurisprudence of Justice Sandra Day O'Connor. Through analysis of O'Connor's personal biography and a series of opinions written over her tenure on the Supreme Court, I find that O'Connor reached an incremental balance between the sometimes conflicting goals of protecting the rights of the states and individuals, resulting in a unique rights-based approach to federalism.
\end{abstract}




\section{Introduction}

"Liberty finds no refuge in a jurisprudence of doubt." So wrote Justices Anthony Kennedy, Sandra Day O'Connor, and David Souter at the beginning of the plurality opinion in Planned Parenthood v. Casey. ${ }^{l}$ While the opinion is a joint work of the three justices, O'Connor's influence on it is clear, even in the opening words. This sentence reveals much about her approach to law and the role of the Supreme Court. We can best demonstrate this approach by asking: what is a jurisprudence of doubt? For O'Connor, at least, such jurisprudence is not the same as a jurisprudence of skepticism. Skepticism is a part of inquiry, and inquiry is an essential to law and the duties of the Court. Rather, a jurisprudence of doubt is one that threatens to unsettle established law and to overturn fundamental liberties that Americans have come to rely on.

Casey demonstrates this reasoning. The justices wrote in their joint opinion that a generation of Americans had planned their lives around the presumption that a legal right to abortion exists. Affirming the essential holding of Roe v. Wade ${ }^{2}$, O'Connor and her co-authors rejected the jurisprudence of doubt that could unsettle Roe's liberty interest. They also rejected the trimester-based structure of Roe. In its place, they adopted the "undue burden" standard O’Connor had been developing for a decade. ${ }^{3}$ This jurisprudential balancing act simultaneously gave the liberty at stake a refuge while also recognizing a legitimate interest in and ability for states to regulate access to such medical procedures. ${ }^{4}$

\footnotetext{
1505 U.S. 833 (1992).

${ }^{2} 410$ U.S. 113 (1973).

${ }^{3}$ Biskupic, Joan. Sandra Day O'Connor: How the First Woman on the Supreme Court Became Its Most Influential Justice. New York: Harper Collins, 2005. pp. 269-270.

4 The terms "state" and "states" are used interchangeably within this text. Both terms are used to refer to state governments within the United States. For the sake of simplicity, lower levels of government (i.e. city and county) may also be incorporated into these terms, depending upon the context.
} 
The balance struck in Casey is typical of O'Connor: incremental decisions that weave their way among a respect for the federal system, precedent, and the rights of the individual, all dependent upon the facts of the case. Put another way, O'Connor described her priorities in (and the limitations upon) the act of judging as including "concerns for the integrity of the Court, the operation of the collective decision-making process, and, most important, the law itself - as embodied in the Constitution, congressional statutes, and the Court's prior case law." 5 She rarely, if ever, lost sight of these elements in the process of deciding, and usually managed to strike a balance among them, as demonstrated by Casey. This nuanced approach to judicial decision-making often cast her as the deciding vote on an otherwise divided Court and made her the Supreme Court's "most influential justice." Indeed, sources ranging from biographer Joan Biskupic to the Washington Post viewed her as sufficiently influential to refer to her quartercentury tenure as the O'Connor Court rather than the Rehnquist Court. ${ }^{7}$

This recognition of her influence is neither universal nor is it necessarily effusive praise. The same nuanced, incremental approach that gave her such influence on the Court also brought with it more than its share of criticism. Some scholars and observers of the Court raised concerns about the precedential value of O'Connor's decisions. Critics reported by Biskupic (e.g. Rosen, Ponnuru, and Segall) suggested that she did not articulate clear legal principles and, as a result, did "not provide enough stability, predictability and transparency to differentiate legal rules from personal preferences." ${ }^{\prime 8}$ In other words, her decisions were too narrow and of little precedential value to other courts who did not benefit from the presence of O'Connor. To these critics, O’Connor offered little in the way of constitutional principle or legal precedent. Her

\footnotetext{
${ }^{5}$ O'Connor, Sandra Day. The Majesty of the Law. New York: Random House Press, 2003. p. 195.

${ }^{6}$ Biskupic, pp. 269-271.

${ }^{7} \mathrm{http}: / /$ www.washingtonpost.com/wp-dyn/content/article/2005/07/01/AR2005070101835.html

8 Biskupic, p. 287.
} 
colleagues were sometimes among her harshest critics. Justice Antonin Scalia pointed out in dissent that the tests and narrow decisions that O'Connor advanced in many instances did not provide "appropriate standards" to be applied consistently.

Where, then, is liberty to find its refuge for Justice O'Connor? The picture that emerges at the end of her tenure is that of a centrist jurist widely thought of as influential but also as lacking a clear judicial philosophy. Were this truly the case, the language used in Casey might be better attributed to Kennedy or Souter, since both were (and, in Kennedy's case, remain) more willing to provide the sweeping constitutional answers that O'Connor avoided. This difference can be seen in Lawrence $v$ Texas. ${ }^{10}$ The majority opinion, written by Kennedy, struck down sodomy laws and was of sufficient scope to expand the right of privacy to protect all consenting adult sexual behavior, including same-sex relationships, through the Due Process Clause of the Fourteenth Amendment.

O'Connor concurred in that decision, but on narrower equal protection grounds, arguing that such laws could no longer survive such a challenge and were democratically untenable. She agreed with the majority's conclusion - that sodomy laws were unconstitutional - but on her typical narrower grounds and with an eye to what would be democratically tolerable to other citizens in similar circumstances (in this case, heterosexuals choosing to engage in prohibited behaviors). Indeed, in many cases, O'Connor avoided an answer to constitutional questions at all. Instead, she often confined herself instead to the facts of the case and balancing tests that weighed various interests against one another. Still, I would contend that to suggest that she lacked any clear principles is an overly broad claim. Certain elements of her judicial philosophy - which can easily be termed principles - are clear and indisputable.

\footnotetext{
${ }^{9}$ Capitol Square Review Board v. Pinette, 515 U.S. 768 (1995).

${ }^{10} 539$ U.S. 558 (2003).
} 
Foremost among them is her devotion to states' rights. For O'Connor, part of the genius of the Constitution is its federal system. She joined Chief Justice Rehnquist and others in retrenching it as a force in American politics. As a former state legislator and judge, O'Connor was uniquely positioned on the Court to favor the state. In practice, she did. Waltenburg and Swinford suggest that among justices in the past half century, only Justice John Marshall Harlan II was more deferential to the states than O'Connor. ${ }^{11}$ Even Rehnquist, the archetypal conservative jurist, ranks slightly behind O'Connor in their evaluation. ${ }^{12}$ It would seem that federalism and the power of the state is one place, at least, where liberty may find its refuge. The nature of the Casey suggests this idea, leaving reasonable regulations (or deregulation) on abortion to the states.

As this brief analysis of O'Connor's legacy and jurisprudence suggests, however, nothing for her is unqualified, even her support of states' rights. O'Connor may well belong to that branch of American political thought that views the Constitution as a compact between the states and the federal government. This view also favors state over federal power, but what she appreciates most is the dual system of federalism. She favored state legislatures and courts whenever possible (usually at the expense of federal power) and as a result often found the federal government had overstepped its limits. States' rights, in theory and practice, advanced during the years of O'Connor's service.

Despite this fact, there is at least one identifiable area of federalism where she was more circumspect: balancing the rights of the individual against those of state government. ${ }^{13}$

\footnotetext{
${ }^{11}$ Waltenburg, Eric and Bill Swinford. Litigating Federalism: The States Before the U.S. Supreme Court. Westport: Greenwood Press, 1999. pp. 32-33.

${ }^{12}$ Ibid, pp. 32-33.

${ }^{13}$ The term "individual" and "individual rights" in this text will sometimes be applied to cases that do not immediately affect individuals. I extend these terms to cases that also involve the exercise of rights by organizations such as the press and religious organizations that fall under the broad heading of "civil society" organizations. It
} 
O'Connor was more open to challenges to abuses of state power. Despite her deserved reputation as a states' rights advocate on the Court, she recognized certain limits on state power as equally fundamental to the functioning of our federal system. In the ensuing text, I will present a series of cases testing the limits of the expressive and religious clauses of the First Amendment as well as the right to privacy against the state. In these decisions, Justice O'Connor struck a unique balance between the interests of the state and the need for our democratic system to empower individual participation in political and civil life, a balance that I call "expressive democracy."

The following text will demonstrate this unique balance between the state and the individual in O'Connor's jurisprudence of federalism. In part two, I will explore the definitions, theoretical and practical, of federalism and expressive democracy and the role they play in the Constitution. Part three explores O'Connor's general jurisprudence of federalism and which experiences shaped her approach to the federal relationship that favored the states. By analyzing a series of cases, the fourth part lays out the argument for O'Connor's approach to the individual rights identified above. The fifth part will analyze my argument and contrast my own approach to understanding O'Connor's jurisprudence of federalism with others, using Wechsler and Ely. The conclusion brings these elements together, ultimately arguing that expressive democracy offers a launching point for identifying a broader judicial philosophy for Justice O’Connor.

will be made clear in ensuing sections how these organizations are important to expressive democracy and are relevant to individual rights. 


\section{Constitutionalism, Federalism, and Expressive Democracy}

Before beginning any discussion of how Justice O'Connor balances the interests of the state and individual rights, I must first analyze the three concepts that will inform much of my discussion: constitutionalism, federalism, and the term "expressive democracy." The following section will lay out these three ideas in some detail, providing definition and context for my approach to them as we move forward. This background is necessary in order to move into the larger part of the project: the analysis of O'Connor's jurisprudence.

\section{a. Constitutionalism}

Because the Constitution is the foundational document of American democracy, it is an excellent starting point. Subject to endless and open debate about an infinite variety of interpretations, it would be beyond the scope of this project to attempt to definitively explain the Constitution. Careers and entire institutions are built around just the question, "What does the Constitution mean?" That said, there are some relatively uncontroversial positions that one can accept about the Constitution in order to have an informed discussion. One particularly useful (and hopefully uncontroversial) interpretation for the purposes of this text was articulated by John Hart Ely: the Constitution is a document "ensuring a durable structure for the ongoing resolution of policy disputes." ${ }^{14}$ While not so sweeping in scope as Justice William Brennan's living constitution or Justice Stephen Breyer's active liberty, this definition presents a useful and more practical approach to understanding the Constitution. ${ }^{15}$

\footnotetext{
${ }^{14}$ Ely, John Hart. Democracy and Distrust: A Theory of Judicial Review. Cambridge, MA: Harvard University Press, 1980. p. 90.

${ }^{15}$ See Brennan, William. "Why Have a Bill of Rights?" Oxford Journal of Legal Studies. 9.4 (1989): pp. 425-440, and Breyer, Stephen. Active Liberty: Interpreting Our Democratic Constitution. New York: Knopf, 2005.
} 
The document - along with the traditions and case law that have developed around it have managed to provide the United States with one of the world's most enduring democracies. Though the Constitution was unable to settle the national debate over slavery, it has otherwise been largely successful in providing a stable government and resolution of policy disputes. This, then, is the basic approach I will take when discussing the Constitution in the context of expressive democracy. This understanding also informs, but does not guide, my interpretation of O'Connor's jurisprudence. The nature of her work carries her far beyond the limits of this basic definition.

\section{b. Federalism}

If the Constitution is a structure for the ongoing resolution of policy disputes, federalism is one of the critical elements of that structure. The Constitution does not expressly mention the term federalism, but it implicitly creates a dual structure of government cognizant of states as important governmental actors in their own right. By virtue of the Tenth Amendment and the Supreme Court's case law, powers that are not granted to the federal government have typically been reserved to the states. While the Supreme Court has vacillated between emphases on state versus federal power, federalism has remained a constant point of contention in our governing system.

Still, some scholars have questioned the viability of federalism as a concern in the modern era. Harry Wellington has written that "contemporary technology, a population moving frequently across state lines, and the expanding role of the federal government in law enforcement have made America too much one country for considerations of federalism to sustain at a constitutional level." 16 It must be noted that Wellington wrote before the "reinvigoration" of federalism by the Rehnquist Court. His position was vitiated (or at least

\footnotetext{
${ }^{16}$ Ely, p. 37.
} 
rejected) as the combined appointees of Presidents Nixon, Reagan, and Bush came together to breathe new life into federalism and states' rights. The emphasis placed by the conservative justices of the Rehnquist Court on states' rights - led by Rehnquist and O'Connor - has helped to define the modern American political landscape. But how?

Theories of federalism are nearly as varied as interpretations of the Constitution. At least one "fact" about federalism has generally been accepted by the Supreme Court: those powers that are not textually granted to the federal government are reserved to the states. McCulloch $v$. Maryland established that specifically granted powers may be expanded through the Necessary and Proper Clause, but what precisely is considered "necessary and proper" for Congress (or other branches) to exercise their powers has changed over the years. ${ }^{17}$ The exact scope of federal powers has often been decided through Commerce Clause cases. ${ }^{18}$ The practical results of these decisions have been the recognition of concepts like expressed, enumerated and reserved powers.

The Tenth Amendment defines, to some degree, the relationship between the states and the federal government. It effectively leaves to the states much of the practical business of governing, through the use of police powers. Education, taxation, regulation of business, and criminal justice, to name just a few policies and procedures, are left to varying degrees to the states. The federal government influences all areas traditionally seen as part of a state's police powers, but it does not monopolize any. Though the Constitution and laws made by Congress are always supreme, states are powerful actors in their own right. As a result, many of the nation's policy disputes are devolved or settled at a local level rather than a national one, in line

\footnotetext{
${ }^{17} 17$ U.S. 316 (1819).

${ }^{18}$ See Gibbons v. Ogden, 22 U.S. 1 (1824), United States v. E. C. Knight Co., 156 U.S. 1 (1895), West Coast Hotel Co. v. Parrish, 300 U.S. 379 (1937), Wickard v. Filburn, 317 U.S. 111 (1942), Heart of Atlanta Motel Inc. v. United States, 379 U.S. 241 (1964), United States v. Alfonso Lopez, Jr., 514 U.S. 549 (1995), and United States v. Morrison, 529 U.S. 598 (2000).
} 
with the theory that local answers to problems are often the best. These local solutions are always subject to federal limitations - especially protections that apply to both the federal and state governments, drawn almost entirely from the Bill of Rights and subsequent amendments. Despite Hamilton's belief that the Constitution itself was a guarantee against abuse by the federal government, these amendments have become an important source of protections for citizens and the source of expressive democracy.

\section{c. Expressive Democracy}

So far, I have discussed the concept of expressive democracy, but no clear definition has been offered. I argue that expressive democracy is an understanding of the Constitution - and the Bill of Rights generally but especially the First Amendment - that places emphasis on personal freedom and participation in both political and civil life. A necessary element of expressive democracy is the structure of the Constitution and the government it creates, the vehicle for the resolution of policy disputes defined by Ely. This interpretation of the Constitution balances the interests and powers of government (i.e., the Constitution's structural elements) against the rights of the people (i.e., the freedoms and protections guaranteed by the Bill of Rights and subsequent amendments). While all of the freedoms and protections in the amendments are important to the smooth functioning of government and citizen participation in political and civil life, I focus on some that I identify as more important than others for the purposes of this text. In this analysis, I focus on the expressive and religious protections of the First Amendment, as well as the right to privacy, and the way that Justice O'Connor has personally shaped them. The relationship between freedoms and federalism finds its fulcrum in O'Connor's approach to the question of the relationship between the state and the individual. 
I focus on these rights when describing expressive democracy for two reasons. First, they are among the most important and continually controversial to American democracy in general. Few rights have had more challenges and tests come before the various branches of government than the freedoms of speech, religious practice or, in recent years, privacy. They remain timely debates. Since the incorporation of the Bill of Rights to the states, they have come to bear on every level of government. Case law no longer merely addresses these freedoms in the context of the federal government, but also in the context of the ability of the states to control the individual. These rights are also among the most important in the Constitution. Few rights are more fundamental to participation in political life than the freedom of speech. Similarly, few rights are as essential to leading a free and fulfilling civil life as the free exercise of religion or the right to privacy that Casey demonstrates so many men and women have planned their lives around.

Second, the selected rights and cases represent a unique approach in Justice O'Connor's general federalist jurisprudence. In other areas of federalism, O'Connor was an unstinting ally of the states. These rights and cases are exceptions to that general rule. O'Connor found cause to decide that the nature of political and civil life required more attention to the individual. It could be sufficient to say that the exercise of powers by the state must be limited by federal protections for her, but that would not go far enough. For O'Connor, something about the nature of federalism itself demands greater protection for the individual and lends itself to the idea of expressive democracy.

\section{i. Expressive Democracy and Federalism}

As discussed previously, the Bill of Rights did not originally apply to the states. With the ratification of the Fourteenth Amendment came the slow incorporation of its various guarantees 
to the states by the Supreme Court. Before the dissents of Justice Harlan I argued for incorporation, Barron v. Baltimore guided the Supreme Court, meaning that the amendments did not limit state power. ${ }^{19}$ In theory, states were free to regulate and limit the rights of citizens with a much freer hand than the federal government. One needs look no farther than Jim Crow laws to realize the potential abuses such a system could produce. The role of the states was thus discredited for many Americans in the wake of the civil rights movement. There was a general sense that states could not be trusted to protect the rights of the minority. This runs counter to the expectations of some of the Framers.

From the very beginning of the Constitution, it was expected that federalism would serve as one of the guarantees against abuse of power by either level of government. In Federalist no. 28, Hamilton asserts that the state and federal governments will serve as checks upon each other, each preventing the usurpation of too much power by the other. ${ }^{20}$ In Federalist no. 51, Madison discusses the "double security" of federalism, suggesting that such division of government will serve to protect the rights of the people and prevent injustice. This is part of Madison's broader argument about the need for checks and balances in government. ${ }^{21}$ More recently, Daniel Elazar has distilled the arguments of the Federalist Papers for federalism as a check upon national power by suggesting that they create, "a balancing of interests, voices and diversity in such a way that there is no permanent majority but rather that all majorities are aggregates of the various minorities that express their interests." 22 Elsewhere, he summarized this view with the suggestion that "federalism is designed to prevent tyranny without preventing governance."23

\footnotetext{
1932 U.S. 243 (1833)

${ }^{20}$ See Federalist Paper \#28.

${ }^{21}$ See Federalist Paper \#51.

${ }^{22}$ Elazar, Daniel. "Federalism, Diversity and Rights.” In Katz, Ellis and G. Alan Tarr, Ed... Federalism and Rights. New York: Rowman and Littlefield Publishers, 1996. p. 2.

${ }^{23}$ Howard, A.E Dick. "Does Federalism Secure or Undermine Rights?” In Katz, Ellis and G. Alan Tarr, ed.

Federalism and Rights. New York: Rowman and Littlefield Publishers, 1996. p. 12.
} 
Elazar's work was part of a broader trend in the latter half of the $20^{\text {th }}$ century that sought to rehabilitate federalism. Both in scholarly work and in the courts, federalism was revisited. State courts began to reassert themselves, and the national courts began to regain faith in the ability of state governments to respect and amplify diversity in the United States. The dispersion of power that the Framers of the Constitution had in part advocated was once again viewed in a positive light, and no longer as a peril. Brandeis' ringing words once again seemed to be true, coming out of dissent into the main stream of law: "It is one of the happy accidents of the federal system that a single courageous state may, if its citizens choose, serve as a laboratory, and try novel social and economic experiments without risk to the rest of the country." 24

While the 'experiments' of Jim Crow laws obviously failed, scholars and the judiciary seem once again willing to allow states some experimentation, subject to the constraints of federal protections. For A.E. Dick Howard, federalism was a force that encourages "localism, pluralism, and diversity alongside it." ${ }^{25}$ The classic formulation of states' rights advocates local solutions for local problems - here came to life. As Howard pointed out, part of the function of federalism is as a kind of classroom. Citizens can participate at the lowest level of government - school boards, neighborhood associations, city councils - where the values of community and democratic principles are best inculcated. ${ }^{26}$ It is here that expressive democracy comes into play. Local government provides solutions for local problems. State governments disperse power and prevent the aggregation of too much power at the federal level. In turn, federal limitations, including those identified as critical to expressive democracy, provide the structure and rights in which citizens can most effectively participate at each level of governance and in civil society.

\footnotetext{
${ }^{24}$ New York Ice Co. v. Liebermann, 285 U.S. 262 (1932). (Brandeis, J., dissenting).

${ }^{25}$ Howard, p. 11.

${ }^{26}$ Howard, pp. 13-14.
} 


\section{Justice O'Connor and Federalism}

When Sandra Day O'Connor sat before the Senate Judiciary Committee as the first female nominee for the Supreme Court, there was much speculation but little certainty what the future would bring. Confirmation testimony for potential justices had become more of a formality, marked by senatorial grandstanding and nominees issuing general statements rather than specific answers about questions of law. Senators asked their questions without expecting (but perhaps still hoping for) substantive answers; nominees have gone through lengthy preparations and were likely to deliver nothing but the blandest of answers.

A review of the "conversation" between the committee and the nominee thirty years later confirms this. Little was revealed in the way of substantive clues about the path that Justice O'Connor would walk on the Court; more is revealed about the concerns and legal controversies of the day. Common topics included the usual questions about judicial philosophy as well as more specific questions about the evidentiary rule, access to the federal courts, abortion, and the status of women. One common theme both the senators and the nominee returned to consistently was drawn from O'Connor's background. Not her Western heritage, nor her experience as a female lawyer, but rather her unique (for Supreme Court nominees) combination of service as a state legislator and state judge.

As a result of this experience, her opinions about the nature of federalism and the role of the states in government (especially legislatures and courts) were explored in detail. O'Connor anticipated this line of questioning. She opened her testimony before the committee and country, in part, with the following:

I want to make only one substantive statement to you at this time. My experience as a State court judge and as a State legislator has given me a greater appreciation of the important role the States play in our federal system, and also a greater appreciation of the separate and distinct roles of the 
three branches of government at both the State and the Federal levels. Those experiences have strengthened my view that the proper role of the judiciary is one of interpreting and applying the law, not making it. ${ }^{27}$

Bland though the statement may be, it is not without substance. Here we see what has already been established as one of the hallmarks of O'Connor's jurisprudence: the importance of the state. She affirms that her own experience, both as state legislator and state judge, will inform her approach on the Supreme Court. Beyond the testament to the limited role of the judiciary - a separate analysis both fascinating in its potential and beyond the scope of this project - there are hints that we can tease out. What O'Connor refers to as "the separate and distinct roles of the three branches of government at both the State and the Federal levels" would become a critical component of her judging.

Waltenburg and Swinford established that, over her tenure, O’Connor was among the justices friendliest to states' rights. She was outdone only by the second Justice Harlan. This is confirmed by other scholars. Stephen Wermeil described O’Connor thus:

If there is any unifying theme to Justice O'Connor's opinions... it appears to be her own brand of federalism. She is strongly motivated by her own abiding faith in good government at the state level and her belief that the Framers of the Constitution envisioned a genuine partnership of shared powers between the federal government and the states. Her experience as a state legislator and judge gives her a degree of trust in state government and state courts that goes well beyond that of her colleagues. ${ }^{28}$

Such descriptions of O'Connor's jurisprudence abound throughout scholarly analysis of her. She is (rightly) painted as a friend of the states and an advocate for the Rehnquist Court's dual federalism. Most of the published analyses have focused on the legal aspects of this federalism. I will come to my own brief discussion of them shortly. First, however, aspects of O'Connor's background that came to bear on her decision-making should be discussed. Sometimes, it is not enough simply to discuss what a particular justice decides or what their overarching judicial

\footnotetext{
${ }^{27}$ From the Government Printing Office's online publication of the Senate Judiciary Committee: The Nomination of Judge Sandra Day O'Connor of Arizona to Serve as an Associate Justice of the Supreme Court of the United States, p. 57. These files can be accessed at http://www.gpoaccess.gov/congress/senate/judiciary/sh-j-97-51/browse.html.

${ }^{28}$ Wermeil, Stephen J. O'Connor: A Dual Role: Introduction. 13 Women's Rts. L. Rp. 129, 139 (1991).
} 
philosophy might be. Sometimes, biography can give us insight into the individual that is critical to understanding the subtle nuances of their life and, ultimately, their judicial philosophy. To understand O'Connor's devotion to federalism and her balancing between the power of the state and the individual, we must first look to her background.

\section{a. O'Connor's Early Life}

Many students of the Court and informed citizens alike would be surprised how much of Justice O'Connor's story has become ingrained in our collective memory. Many of us have heard one story that has been repeated time and again. The future justice, who graduated in the top ten percent of her class at Stanford Law School and had served on the editorial board of its law review, received no job offers save for a position as a legal secretary. ${ }^{29}$ Thanks to her confirmation hearings and the surrounding White House press campaign, we also know of her Western roots, her devotion to being a mother and a wife, and her background as a state legislator and judge.

All of these were oft discussed at the time of her nomination. O'Connor was not simply a woman, but the right kind of woman: feminine and unthreatening. ${ }^{30}$ This image was built by O'Connor herself over her political career in Arizona. After all, this is the woman who would often address gatherings with the line, "I come to you tonight wearing my bra and my wedding ring." 31 These elements, combined with her professional background, led to a meeting with President Reagan and an almost instant decision by the president that she was the right nominee; he did not meet with any other nominees after he met O'Connor. ${ }^{32}$ Her nomination was assured after that meeting. Her confirmation followed soon after.

\footnotetext{
${ }^{29}$ Biskupic, p. 28.

${ }^{30}$ Biskupic, pp. 4-5; pp. 74-75.

${ }^{31}$ Biskupic, p. 4.

${ }^{32}$ Biskupic, pp. 76-78.
} 
Reagan's affinity for O'Connor went beyond her appeals to traditional notions of family and femininity. O'Connor and Reagan both shared a connection in their home in the western United States. Unlike Reagan, O'Connor was a genuine product of the West. The president was born in Illinois but migrated to California as a young man, which would become his adopted home. ${ }^{33}$ Reagan and O'Connor also shared a connection in that they shared a love of ranch life, but again, O'Connor had the upper hand. Reagan owned ranches much of his life, and in 1974 he purchased the most famous of his ranches, Rancho del Cielo. ${ }^{34}$ These were experiences gained as a grown man and successful actor. O'Connor was the "real deal." She was born just as the Great Depression began to ranching parents Henry and Ada Mae Day, owners of the Lazy B Ranch.

According to O'Connor, life on the Lazy B was difficult but filled with great beauty. While much of her schooling took place away from home, her breaks and summers were spent at the ranch. ${ }^{35}$ She learned much of the hardship that running a ranch in the heart of the Depression could inculcate, but she also learned from the example of both parents, nicknamed "MO" and "DA." Her mother taught her much of the feminine demeanor that would suit her so well later in life, but also insisted on her daughter receiving an education, being an educated woman herself (Ada Mae Day had a college degree, a rarity for women in those days). ${ }^{36}$ These lessons would create much of the potential for O'Connor's political career, but it was from her father that she would learn her politics.

\footnotetext{
${ }^{33} \mathrm{http}: / / \mathrm{www}$. whitehouse.gov/about/presidents/ronaldreagan

34 http://www.yaf.org/RanchodelCieloHistory.aspx

35 Biskupic, pp. 16-20.

${ }^{36}$ Ibid, pp. 12-13.
} 
Henry Day was described by his daughter as a hard but fair employer. ${ }^{37}$ As a rancher and businessman during the Great Depression, he managed to turn his family business around through a combination of hard work, thriftiness, and a refusal to take on debt. ${ }^{38}$ The family was not wealthy, but they survived the Depression debt-free. As beef became a staple food after World War II, profits at the ranch increased. ${ }^{39}$ More importantly, however, Henry "DA" Day was a man of strong political convictions, which he not only lived by but also replicated in his children. It is no secret that Henry Day and the Lazy B benefited from certain programs implemented during the New Deal (a beef-buying scheme primary among them). ${ }^{40}$ Despite this, he was opposed to the expansion of government into business and individual affairs - attitudes common among ranchers and Westerners of his day, who had grown to adulthood with laissez faire attitudes toward business. ${ }^{41}$

Henry Day, like his fellow ranchers, was a firm believer in the self-made man and the value of personal initiative, and was often angered by the social agenda implemented by President Roosevelt and the Democratic Congress. ${ }^{42}$ The family tells a story that, upon the reinstatement of Daylight Saving Time by Roosevelt's administration, Henry Day stated that "now the son of a bitch is telling us when to get up and when to go to bed."43 Henry Day did not have a college education, but he was a voracious consumer of news, subscribing to a variety of newspapers and magazines. ${ }^{44}$ Family dinners were often marked by discussions of politics and

\footnotetext{
${ }^{37}$ O’Connor, Sandra Day and H. Alan Day. Lazy B: Growing Up on a Cattle Ranch in the American Southwest. New York: Random House, 2002.

${ }^{38}$ Ibid, p. 25.

${ }^{39}$ Ibid, p. 26.

${ }^{40}$ Ibid, pp. 25-26.

${ }^{41}$ Ibid, p. 26.

42 Biskupic, pp. 13-14.

${ }^{43}$ Ibid, p. 14.

${ }^{44}$ Ibid, p. 29.
} 
business, where he spared no effort to make his opinions known. ${ }^{45}$ Together, he and his wife impressed the value of personal initiative, hard work, and the value of education in their children. Their example also taught their children the value of a sharp mind and conservative values. While O'Connor may not have shared every opinion of her parents - especially her father - the mark of Henry and Ada Mae Day on their eldest daughter is readily apparent.

\section{b. O’Connor's Professional Life}

The lessons O'Connor received from her parents seemed to have combined to produce a person too good to be true. She learned social skills and a sense of adventure from her mother; hard work and an eye toward thrift and advantage from her father; and gained a keen mind and desire for education from both parents. It would be easy to dismiss this as the idealization of her family by O'Connor and the creation of a mythic "überfrau" by biographers and scholars. It would also be overly hasty to do so. O'Connor is not perfect - I dare say she herself would laugh at the suggestion - but her story is inspirational and, in many ways, seems to be the story of the American dream. Her career as a mother, lawyer, politician and judge are testaments to this fact. While the details of her career are beyond the limits of space and time for this work, we can trace the broad contours of them in order to demonstrate the impact of her upbringing on her career and ultimately her jurisprudence.

The superficial details of her career are easy to trace and can be retold in a quick accounting of facts. After marrying John O'Connor and graduating from Stanford, she travelled abroad with her husband when he was stationed in Germany as a military lawyer. She found work as a civilian attorney for the Quartermaster Corps in $1953 .{ }^{46}$ The O'Connors returned to the United States and settled in Phoenix, Arizona, where O'Connor entered private practice for

\footnotetext{
${ }^{45}$ Biskupic, p. 29.

${ }^{46}$ Ibid, p. 28.
} 
several years before (mostly) ending her practice in 1960 for several years to focus on raising her young children. ${ }^{47}$ In 1965 , feeling her children were old enough so that she could return to the work force, O’Connor found employment as an assistant Attorney General for the state of Arizona. ${ }^{48}$ In 1969 , she was appointed to a recently-vacated seat in the Arizona Senate, where she quickly became an influential member. ${ }^{49}$ By 1973 , O'Connor was elected by her fellow Republicans as Arizona Senate Majority Leader. ${ }^{50}$ In 1975, she left the State Senate and sought election to a newly created Maricopa County superior court judgeship. ${ }^{51}$ She won a difficult primary for the seat, and served in it until 1979, when she was appointed to a vacancy on the Arizona Court of Appeals. ${ }^{52}$ In 1981, she was nominated and confirmed to the Supreme Court of the United States. By this time, O'Connor had served in all three branches of her home state's government.

This is only the thinnest of biographies, and space limits the provision of the details of her career. ${ }^{53}$ There are several elements to her success that have been consistently remarked upon and that can give us insight into O'Connor both as a professional and as a justice. Immediately obvious is the high-achieving trajectory of O'Connor's career path. She was the first female majority leader among state legislatures, one of a small line of female judges in Arizona, and the first woman to serve on the United States Supreme Court. This was a result of hard work, a centrist approach, and constant cultivation of contacts by O'Connor. Biographies are full of more instances than can be cited here of O'Connor's commitment to causes. She was a reliable Republican partisan throughout her career. She worked for and supported Barry

\footnotetext{
${ }^{47}$ Ibid, pp. 28-30.

${ }^{48}$ Ibid, pp. 34-35.

${ }^{49}$ Ibid, pp. 37-38.

${ }^{50}$ Ibid, p. 56.

${ }^{51}$ Ibid, pp. 64-65.

${ }^{52}$ Ibid, p. 68.

${ }^{53}$ Joan Biskupic's biography is a wonderful sketch of the early and professional life of the justice. For the curious reader, it is highly recommended.
} 
Goldwater's senatorial and presidential campaigns. ${ }^{54}$ When friend William Rehnquist was nominated as an associate justice, she waged a tireless campaign of support. ${ }^{55}$ During her tenure as a state senator and majority leader, she was also known as an effective legislator, wellprepared with facts and ready to build bridges wherever possible. ${ }^{56}$

Never an ideologue, O’Connor was known as a centrist throughout her political and legal careers. She never strayed too far from the middle nor associated herself with controversial positions. Her positions on women's rights provided a clear example. O’Connor took steps to support women's rights, not out of a devotion to the cause of feminism but rather out of a devotion to equal opportunity.. Remember, this is the woman who declared when she came before crowds that she was "wearing [her] bra and her wedding ring." She was a leader in the Arizona legislatures' efforts to repeal a law limiting women's work days to no more than eight hours. ${ }^{57}$ This was an effort to overturn the kind of paternalist legislation and social views that viewed women as requiring more protection than men. Speaking in favor of repealing the law, O’Connor stated, "Let's give women a chance for a better life and a bigger pocketbook.",58

For O'Connor, repealing this law would create, rather than limit, opportunity for women; a sensible position to be taken by a woman raised and schooled in a world where individual initiative should be rewarded. On abortion rights and the Equal Rights Amendment (ERA), both controversies of the day, O’Connor was lukewarm. She opposed restrictions on abortion as a state senator, and voted for the repeal of Arizona's abortion prohibition. ${ }^{59}$ She supported the ERA, but again, as a matter of creating equality rather than an embrace of feminism. ${ }^{60}$ She was

\footnotetext{
${ }^{54}$ Biskupic, pp. 34-36.

${ }^{55}$ Ibid, pp. 44-48.

${ }^{56}$ Ibid pp. 52-61.

${ }^{57}$ Ibid, p. 52.

${ }^{58}$ Ibid, p. 52.

${ }^{59}$ Ibid, p. 58.

${ }^{60}$ Ibid, p. 59.
} 
sympathetic to the cause of women's rights, but she was neither a leader nor an outspoken advocate for them. Instead, in typical O'Connor style, she led by example and by carrying on in the face of opposition.

As a child, O'Connor learned the value of hard work and individual initiative. She took these lessons to heart and lived them as an adult. They shaped both her career path and her political views. She looked for the best path to make new contacts and to gather political capital. It seems that, as a legislator, she found that by walking a centrist path and balancing the conflicting values of "the boys," as she referred to her fellow senators, she could advance her own interests and legislative goals. Her own hard work won her the accolades of her peers and, more importantly, opened career paths that might have been otherwise closed to her. Having had the opportunity to better her own life, she acted as a senator to give other women the same opportunity. Most importantly, her time working in her local community and state government proved to her the value of individual participation in government and public life. In a commencement address delivered to Gettysburg College in 2008, Justice O'Connor confirmed this conclusion.

In giving advice to the graduating class, she praised the value of starting at the bottom (in business or in government), because those closest to a problem are best able to propose and find solutions. ${ }^{61}$ She stated, "Though it may be years before you have the authority to decide which solutions will be adopted, you can begin right away to generate the ideas that make solutions feasible." ${ }^{\prime 2}$ This is typical O'Connor language, and was marked by her public service even before serving on the Supreme Court. She was more concerned with answers to problems that

\footnotetext{
${ }^{61}$ O'Connor, Sandra Day. Commencement Address. Gettysburg College. Gettysburg, PA, May 9, 2008. The text of the address can be accessed at http://www.gettysburg.edu/commencement/2008/oconnor.dot.

${ }^{62}$ Ibid, par. 12.
} 
could be solved than in taking an ideological stance. Elaborating on her lifelong belief in the value of participation in the community, the justice said:

Now, the second suggestion I have to help make your life meaningful and fulfilling is to become involved in the community in which you find yourself. Become a part of it by participating in it directly, whether as a volunteer worker, or a representative in some community agency or institution, or simply as a citizen who persuades others to take needed action. The individual can and does make a difference even in this increasingly complex world of ours. ${ }^{63}$

Critically, she also emphasized that the national government is not the source of "the most important work in our nation... It is being done all over our country, in every state, in every community. Wherever you go, wherever you live, you can be part of solving our nation's problems. We have 50 separate state laboratories working on solutions."64 The centrist jurist, looking back on her own career, confirmed the value of local communities and governments and the states as the best places for individual initiative to foster and grow. I will return to this point later in my discussion of O'Connor's balance between state and individual rights and expressive democracy. For now, it is enough to say that the connection between federalism and individual participation in civil and public life is clear from O'Connor's own words.

\section{c. O’Connor's Federalism in Practice}

Justice O'Connor is undoubtedly a champion of state power, usually at the expense of the federal government. We can establish this from her words, her personal history, and from scholars who have analyzed her legacy. State power may be too broad a term, though. While any justice of the Supreme Court has the chance to shape American law and American life in substantial ways, they often leave their mark in specific areas or advance specific theories. Justice Hugo Black is renowned for his influential interpretation of the First Amendment's free speech provision. Justices Oliver Wendell Holmes and Felix Frankfurter are both renowned for their advocacy of

\footnotetext{
${ }^{63}$ Ibid, par. 13.

${ }^{64}$ Ibid, par. 21.
} 
judicial restraint. In recent years, Justice Scalia has been influential in cases involving the Confrontation Clause of the Sixth Amendment. ${ }^{65}$ The earlier Wermeil quotation suggests that federalism - "her own brand of [it]" - is one of the defining hallmarks of O'Connor's jurisprudence. Like many terms in the constitutional jargon, though, the term federalism is ambiguous. It requires definition. Here, it requires definition in the context of O'Connor's "brand."

Professor Erwin Chemerinsky has identified four areas of Justice O'Connor's federalism jurisprudence as particularly important. ${ }^{66}$ These areas are where her influence on what he calls the Rehnquist (or O'Connor, depending on your perspective) Court's "federalist revival" is most clear. ${ }^{67}$ These areas are as follows: first, reinvigoration of the Tenth Amendment; second, new limitations on commerce power; third, state sovereign immunity; and, finally, limits on habeas corpus rights. ${ }^{68}$ Of these four areas, limits on habeas corpus were probably the area most important to O'Connor. This can be attributed to her opinions on the role of state courts in the federal system. She was in a unique position on the Supreme Court for a number of years as the only state court judge, until Justice Souter joined the court in $1990 .{ }^{69}$ In a William and Mary Law Review article written before her nomination, O'Connor wrote about the role of state courts

\footnotetext{
${ }^{65}$ Linda Greenhouse discusses Scalia's involvement in Confrontation Clause jurisprudence, and other issues, in a recent blog article for the New York Times. http://opinionator.blogs.nytimes.com/2011/03/09/justice-scaliaobjects/?partner=rss\&emc=rss. Professor Lisa McElroy, writing for SCOTUSBlog, suggests that "many consider the Confrontation Clause to be "[Scalia's] doctrine." http://www.scotusblog.com/?p=115456.

${ }^{66}$ Chemerinsky, Erwin. Justice O'Connor and Federalism. 32 McGeorge L. Rev. 877 (1991).

${ }^{67}$ Ibid, p. 883.

${ }^{68}$ Ibid, pp. 879-887.

${ }^{69}$ David Souter served as an associate justice of the New Hampshire Superior Court from 1978 to 1983 and as an associate justice of the New Hampshire Supreme Court from 1983 to 1990. Unlike O'Connor, he served for a brief period as a federal judge before being nominated to the Supreme Court when, in 1990, he was appointed to the United States Court of Appeals for the First Circuit. For more information about Justice Souter, see Yarbrough, Tinsley. David Hackett Souter: Traditional Republican on the Rehnquist Court. New York: Oxford University Press, USA: 2005.
} 
in the federal system. ${ }^{70}$ The general thrust of the article, suggested (accurately) by Senator Joe Biden during her confirmation hearings, was that the state courts should be given greater consideration when interpreting and applying the Constitution. ${ }^{71}$

This was a consistent theme throughout her hearings, and remained so in opinions we will discuss during her tenure on the Supreme Court. O'Connor was an advocate of restricting access to the federal courts, especially through limiting habeas corpus petitions. This was not a malicious position against the rights of the accused; rather, it was born out of her faith that state courts could deal with issues of law at least as well the federal courts. For O'Connor, the state courts should be respected as fully as the federal courts, and their decisions should only be subject to federal review when the lower courts got a question of law wrong in some way. ${ }^{72}$ Most central to this was the issue of finality: for O'Connor, habeas corpus undermined the conclusions reached by state courts. ${ }^{73}$ Restricting, but not removing, habeas corpus was a key recognition of the importance of state courts in the federal system for her. Also vital to the advancement of state courts in the federal system was O'Connor's decision in Michigan v. Long, which suggested that state courts could avoid review by the Supreme Court if they "clearly and expressly" declared that their decisions were based on state, rather than federal, law. ${ }^{74}$ According to Joan Biskupic, expanding the role of and respect for the state courts was one of the areas of law that O'Connor had truly made her own. ${ }^{75}$

In the other areas identified by Chemerinsky, O'Connor remained persuasive, but her role may have been less influential. Early in her tenure on the Court, she wrote a dissent in Federal

\footnotetext{
${ }^{70}$ Day O'Connor, Sandra. Trends in the Relationship Between the Federal and State Courts from the Perspective of a State Court Judge. 22 Wm. \& Mary L. Rev. 801, 813 (1981).

${ }^{71}$ Biskupic, p. 65.

${ }^{72}$ Ibid, pp. 73-75.

${ }^{73}$ Chemerinsky, p. 886.

${ }^{74} 463$ U.S. 1032 (1983).

${ }^{75}$ Biskupic, pp. 202-204
} 
Energy Regulatory Commission v. Mississippi, adopting the position that to force states to consider the adoption of federal regulations usurped state regulatory power in violation of the Tenth Amendment. ${ }^{76}$ In New York v. United States, she wrote the opinion for the Court which, among other issues, found that a "take title" provision in the Low-Level Radioactive Waste Policy Amendments Act violated the Tenth Amendment, bringing her dissent into the majority. ${ }^{77}$ The "take title" provision would once again have usurped state regulatory authority by requiring states to take possession of and responsibility for radioactive waste within their borders, if they did not comply with the regulatory scheme established by the act. ${ }^{78}$

Justice O'Connor's impact on the limitation on federal commerce clause powers is overemphasized by Chemerinsky. Beginning in 1995, a series of decisions by the court limited Congress' Commerce Clause powers for the first time since the New Deal. ${ }^{79}$ These cases were obviously critical - the Court had a long tradition of deferring to Congress in defining the limits of interstate commerce since the New Deal. That these decisions came down against commerce powers sent a strong message about the evolution of the Court. However, these opinions were written by other justices. There is one concurrence by Justice Kennedy that O'Connor joined which emphasized the need to protect state power and prerogatives. ${ }^{80}$ As part of the majority, rather than author, it is unclear how controlling her views were.

In all likelihood, she had some impact on these opinions, especially the concurrence written by Kennedy, but placing this line of jurisprudence as central to O'Connor herself is a questionable choice. It is better to portray it as central to the general "federalist revival" that occurred over the tenure of the Rehnquist Court. The same could be said of state sovereign

\footnotetext{
${ }^{76}$ Chemerinsky, p. 879. See case: 456 U.S. 742 (1982).

${ }^{77}$ Ibid, p. 880. See case: 505 U.S. 144 (1992).

${ }^{78}$ Ibid, p. 880.

${ }^{79}$ Ibid, pp. 882-883.

${ }^{80}$ Ibid, p. 883.
} 
immunity claims, though O'Connor wrote one opinion in this area: Kimel v. Florida Board of Regents. ${ }^{81}$ Her opinion concerned the Age Discrimination in Employment Act (ADEA). She held that sovereign immunity protected states against claims under the Act because "the burdens the ADEA imposes on state and local governments are disproportionate to any unconstitutional behavior that might exist." ${ }^{\prime 2}$ Beyond this opinion, O'Connor was part of the majority that enforced state sovereign claims against a variety of federal efforts to impose them, but she herself was not the guiding force behind the doctrine's development.

O'Connor's role in the federalist revival that the O'Connor/Rehnquist Court brought about can be summarized with a few general principles. First, she was a part of the majority that brought the concerns of state governments and state power to the front in American politics after a long period in which states' rights had been discredited. She joined with a conservative majority of justices appointed by Presidents Nixon, Reagan, and Bush to reassert state power in our constitutional arrangement. Second, the two areas of federalism jurisprudence where she was most persuasive were, first, empowering state courts through the restriction of habeas corpus petitions and a general respect given to state court decisions, and second, reinvigorating the Tenth Amendment as a bar on congressional usurpation of state power. Finally, I believe that we can see firmly that O'Connor's assertion at her confirmation testimony was correct and provided an essential insight into how this justice would perform. She did indeed demonstrate great respect for the role of the states and the distinct roles of the various branches of government. Perhaps, for the preferences of the federal government advocates, her respect for these roles was too great.

\footnotetext{
${ }^{81}$ Ibid, p. 883. See case: 528 U.S. 62 (2000)

${ }^{82}$ Ibid, p. 884.
} 


\section{The State and the Individual}

Daughter of the west; dedicated Republican; friend of the states; willing - indeed, leading participant in the Rehnquist Court's federalist revival: these are some of the pictures of Justice O'Connor that have emerged so far. There is no doubt now that federalism was one of the cornerstones of her jurisprudence. I have suggested previously that O'Connor's support for state power was not absolute. Where the state's ability to regulate or control individual participation in political and civil life was concerned, O’Connor was circumspect. In these circumstances, her tendency to focus on balancing the competing interests was more pronounced. Importantly, state interests did not always trump individual or social interests in these cases. To demonstrate this, I will examine a series of opinions written by O'Connor throughout her career with an eye toward her method of balancing these interests.

These cases involve the First Amendment's expressive and religious freedoms and the right to privacy identified by the Court. The freedoms are considered in the order listed, and the cases are discussed by decision direction (for or against the state interest) and chronologically. Taken together, they will demonstrate that O'Connor's receptivity to state claims was tempered by constitutional protections that encouraged the participation in political and civil life she so valued. In short, they show that O'Connor's federalism can be interpreted through the lens of expressive democracy. An analysis furthering this argument will be given after the cases are outlined.

a. The First Amendment's Expression Protections

The freedoms of speech, assembly, and the press contained in the First Amendment are widely regarded as among the most important protections in the Constitution. If the Constitution is a 
system for settling ongoing policy disputes, these freedoms are the 'keys to the kingdom' of direct citizen participation in those disputes. They allow citizens to move beyond the act of voting to a fuller, more developed participation in political and civil life without fear of sanction by government authorities. Through free speech, John Stuart Mill's marketplace of ideas flourishes. Through free assembly, citizens are able to take their issues directly to the government. Through a free press, information is (theoretically) freely and fully reported to the population. Without these protections, citizens are restricted and less informed and, ultimately, democracy is less able to function. Without them, citizens cannot engage in the lively debates that best support the democratic process.

These protections were initially directed only toward the federal government. ${ }^{83}$ Through the vehicle of the Fourteenth Amendment, adopted in 1868, these protections have also been incorporated to the states. Freedom of speech and the press were applied to the states in Gitlow v. New York. ${ }^{84}$ Likewise, freedom of assembly has been incorporated against the states since the decision DeJonge v. Oregon. ${ }^{85}$ Incorporation does not imply settled law, however; like every area of constitutional law, there is constant evolution in their interpretation and application. During her term on the Supreme Court, Justice O'Connor wrote a number of opinions that have served to define the application of these rights to state governments.

\section{i. Cases Decided Against the State}

Early in her career, Justice O'Connor wrote her first decision deciding against a state in application of the freedom of the press. In 1971, Minnesota amended a tax structure that had previously excepted "periodic publications" from sales and use taxes such that ink and paper

\footnotetext{
${ }^{83}$ The Supreme Court held this in Barron v. Mayor of Baltimore, 32 U.S. 243 (1833). Chief Justice Marshall, writing for the Court, held that the amendments were clearly intended only to apply to and limit the power of the federal government.

${ }^{84} 268$ U.S. 652 (1925).

${ }^{85} 299$ U.S. 353 (1937).
} 
used in publication were taxed. ${ }^{86}$ Publishers accrued tax debts as a result of the new tax, and proceeded to seek a refund. The Minneapolis Star Tribune challenged the tax as a violation of the freedom of the press and equal protection clauses of the Constitution. ${ }^{87}$ In her opinion for the Court, O'Connor reasoned that "any tax that burdens rights protected by the First Amendment cannot stand unless the burden is necessary to achieve an overriding governmental interest." 88

Finding that the tax threatened the freedom of the press by specifically singling out the press as a class (in the form of newspapers), she found that the tax was unrelated to a specific overriding government interest and thus unconstitutional. This case does not directly concern an individual, but it addresses the relationship between the state and the press. Access to a vibrant press - as O’Connor cites in her decision - was and remains a critical element of democracy. ${ }^{89}$ Further, there is a general interest in recognizing that the "power to tax differentially... gives government a powerful weapon against the taxpayer selected."90 In plain English, the power to tax different people (or entities) differently could be used as a power to tax and therefore punish certain ideas.

O’Connor next weighed the First Amendment against state and local interests, finding in favor of the former, in 1988. ${ }^{91}$ The District of Columbia made it illegal to display signs within 500 feet of a foreign embassy that "tend[ed] to bring that foreign government into "public odium" or "public disrepute.""92 The law further prohibited gatherings of more than three persons within the same zone. The Court's decision shows the balance that O'Connor often struck between interests. She reasoned that the "display clause" was unconstitutional because it

\footnotetext{
${ }^{86}$ Minneapolis Star \& Tribune Co. v. Minnesota Commissioner of Revenue, 460 U.S. 575 (1983).

${ }^{87}$ Ibid, at 577-578.

${ }^{88}$ Ibid, at 582-583.

${ }^{89}$ Ibid, at 584.

${ }^{90}$ Ibid, at 585.

${ }^{91}$ Boos v. Barry, 485 U.S. 312 (1988)

${ }^{92}$ Ibid, at 315.
} 
was a content-based restriction on political speech. ${ }^{93}$ Due to this content-based restriction, despite the assertion of government interests, the law was "inconsistent with the First Amendment."94 The "congregation clause," however, was found acceptable, primarily because the lower court decision here challenged distinguished that only certain acts were prohibited by the congregation clause. O'Connor wrote, "The congregation clause does not prohibit peaceful congregations; its reach is limited to groups posing a security threat." 95 This decision carefully weighs two considerations between the states and the individual: the free-speech rights of politically minded citizens on one hand, and the need of states (and local government) to recognize and forbid certain situations as dangerous.

In 1991, New York's Son of Sam law was challenged before the Court, giving O'Connor another chance to shape the relationship between the states and the First Amendment. ${ }^{96}$ The law was a scheme whereby any profits for a book or other work describing the commission of a crime must be given to the New York City Crime Victims Board to redistribute the money to the victims of said crime. ${ }^{97}$ This law was specifically created in response to publication of the writings of the Son of Sam killer, David Berkowitz. ${ }^{98}$ The law was only invoked in a handful of cases since its enactment in 1977. Each time it was invoked, it dealt with the potential profits of individuals who had committed high-profile crimes. ${ }^{99}$ In 1986, a contract was signed between publisher Simon \& Schuster and mafia criminal Henry Hill. ${ }^{100}$ The Crime Victims Board became aware of the intended publication and invoked the Son of Sam law. ${ }^{101}$ Simon \&

\footnotetext{
93 Ibid, at 321.

94 Ibid, at 329.

95 Ibid, at 331.

${ }^{96}$ Simon \& Schuster, Inc. v. Members of the New York State Crime Victims Board, 502 U.S. 105 (1991).

${ }^{97}$ Ibid, at 109-111.

98 Ibid, at 108 .

${ }^{99}$ Ibid, at 111.

${ }^{100}$ Ibid.

101 Ibid, at114.
} 
Schuster filed suit, claiming the law violated the First Amendment, after the Crime Victims Board demanded payment. ${ }^{102}$

In her opinion for the Court, Justice O'Connor agreed that the law violated the First Amendment. She wrote that whether the speaker in this case was Henry Hill, the author, or Simon \& Schuster, the publisher, the effect was the same: the law "plainly imposes a financial disincentive only on speech of a particular content." ${ }^{103}$ The law targeted only a specific activity - storytelling - and was not narrowly tailored, and therefore could not stand under the First Amendment. ${ }^{104}$ Much like her decision in Minneapolis Star \& Tribune Co. v. Minnesota Commissioner of Revenue, O'Connor led the majority in weighing the needs for free expression against the state's interest in regulating expression and found the state wanting.

Her next opinion shaping these relationships in favor of the First Amendment over government concerned the firing of a government contractor at the county level. ${ }^{105}$ Umbehr had been a contractor for his county government, hauling trash for a number of years. He was also a political opponent and outspoken critic of the County Commissioners during that time. ${ }^{106}$ Allegedly as a result of his opposition, the Commissioners voted to terminate his contracts, forcing him to renegotiate with cities he had previously served. ${ }^{107}$ He brought suit alleging that he had been terminated as a result of his speech and argued that the firing constituted a violation of his First Amendment rights. ${ }^{108}$ O'Connor, writing for the majority, agreed with the petitioner's argument. She wrote that, "We agree with the Tenth Circuit [judgment] that independent contractors are protected, and that the Pickering balancing test, adjusted to weigh

\footnotetext{
102 Ibid, at 115 .

103 Ibid, at 116 .

104 Ibid, at 123 .

${ }^{105}$ Board of County Commissioners, Wabaunsee County, Kansas v. Umbehr, 518 U.S. 668 (1996), at 671.

${ }^{106}$ Ibid.

${ }^{107}$ Ibid.

${ }^{108}$ Ibid, at 672.
} 
the government's interests as contractor rather than as employer, determines the extent of their protection." 109 The case established the right of public contractors, as well as public employees, to speak freely on political matters. Specifically, the Court held that "the First Amendment's guarantee of freedom of speech protects government employees from termination because of their speech on matters of public concern." ${ }^{\prime 10}$ The same protections extended to public employees (to have their interests in making public comment as a citizen weighed against the governments' interests in regulating speech) were extended to contractors as well.

\section{ii. Cases Decided in Favor of the State}

Justice O'Connor deserves her reputation for incremental decisions and narrowly balancing interests. For every case described above in which she favored the expressive rights of individuals and society over the state, she (literally) just as often favored the state over those rights. Her first decision in favor of states' ability to limit or restrict these rights came from Minnesota. ${ }^{111}$ In this case, the state had established a system for state employees to "meet and negotiate" with their employers. ${ }^{112}$ This required public employers to meet with their employees in order to "exchange views... on policy questions related to their employment." $" 113$ Professional employees engaging in collective bargaining were able - required - to do so through an established representative, who would "meet and confer" with the employer. ${ }^{114}$ The employees selected their representative, empowering him or her to communicate for the employees as a group. ${ }^{115}$ Public employers could only communicate with these representatives and no others as

\footnotetext{
${ }^{109}$ Ibid, at 673. The Pickering balancing test can be found at 568 in Pickering v. Board of Education, 391 U.S. 563 (1968): "The teacher's interest as a citizen in making public comment must be balanced against the State's interest in promoting the efficiency of its employees' public services."

${ }^{110}$ Ibid, at 676.

${ }^{111}$ Minnesota State Board for Community Colleges v. Knight, 465 U.S. 271 (1984)

112 Ibid, at 273.

${ }^{113}$ Ibid.

114 Ibid.

115 Ibid, at 274.
} 
part of "nonmandatory exchanges." "116 Faculty members of Minnesota community colleges who were not part of the state's Faculty Association, which had been designated the sole bargaining representative, filed suit. ${ }^{17}$ They alleged that their First Amendment rights had been violated in being excluded from the process of "meet and confer" and "meet and negotiate" as they were not represented by the Faculty Association.

Writing for the Court, O'Connor distinguished between the right to speak and the right to be heard. She reasoned that the provision was constitutional because the rights to freedom of speech and assembly do not impart an accompanying duty for government to hear or to heed the speaker. ${ }^{118}$ While the faculty members may have a right to speak as public citizens and, in O'Connor's words, as employees, have a "special interest in public policies relating to their employment," they enjoy "no special constitutional right to a voice in the making of policy" because of their position. ${ }^{119}$ For O'Connor, the state has a reasonable interest in basing its policy-making on the majority of employees, who are represented by the Faculty Association, in this case. ${ }^{120}$ There were no violations of the appellee's rights and, as such, the law survived the First Amendment challenge. This case combines with the precedents established by Pickering and Umbehr to show that public employees have a right to speak on political matters and policy issues, but not necessarily to be 'heard,' suggesting that their participation in the policy process is not guaranteed.

Justice O'Connor next ruled in favor of the state when weighing rights to protest. ${ }^{121}$ In the spring of 1985, in the town of Brookfield, Wisconsin, a group of individuals highly opposed

\footnotetext{
${ }^{116}$ Ibid, at $274-275$.

${ }^{117}$ Ibid, at 278 .

${ }^{118}$ Ibid, at 284-285.

${ }^{119}$ Ibid, at 286 .

${ }^{120}$ Ibid, at 291-292.

${ }^{121}$ Frisby v. Schultz, 487 U.S. 474 (1988).
} 
to abortion held a series of protests in public streets outside the home of an abortion provider. After "controversy... and complaints," the town board passed an ordinance that prohibited all protests in residential areas, excepting labor protests. ${ }^{122}$ The original ordinance was repealed after the Court's decision Carey v. Brown. ${ }^{123}$ It was replaced with a more general prohibition on protesting "before or about the residence or dwelling of any individual in the Town of Brookfield." ${ }^{124}$ The ordinance was challenged on First Amendment grounds as an unreasonable prohibition on protest in a public forum.

In its decision, the Court rejected the Town of Brookfield's argument that the streets were considered nonpublic forums. ${ }^{125}$ That being the case, O'Connor went on to consider the prohibition itself. She reasoned that the prohibition did not target particular content, but instead served to protect residents in their own homes - a reasonable government interest. ${ }^{126}$ Further, the prohibition on picketing and protesting was narrowly tailored. Other forums and forms of expression remained open to protestors. ${ }^{127}$ These conclusions led the majority to rule that the prohibition on protests in front of individual residences was constitutional, a reasonable and content-neutral limit on "speech directed primarily at those who are presumptively unwilling to hear it." 128

The Court again ruled for the states in Leathers v. Medlock. ${ }^{129}$ The State of Arkansas's gross tax structure imposed taxes on all "tangible personal property and specified services."130 Certain goods and services are exempted from the tax, such as the sale of newspapers and

\footnotetext{
${ }^{122}$ Ibid, at 476-477.

${ }^{123}$ See case: 447 U.S. 455 (1980).

${ }^{124}$ Ibid, at 477.

125 Ibid, at 480-481.

126 Ibid, at 482-483.

127 Ibid, at 484.

${ }^{128}$ Ibid, at 488 .

${ }^{129}$ Leathers, Commissioner of Revenues of Arkansas v. Medlock, 499 U.S. 439 (1991).

${ }^{130}$ Ibid, at 441.
} 
magazines. ${ }^{131}$ In 1987, Arkansas passed legislation that extended the sales tax specifically to cable television, which was previously unlisted among those services to be taxed. ${ }^{132}$ A class action suit brought to the Arkansas Chancery Court argued that taxation of cable services, while newspapers, magazines and satellite services remained exempt, violated both First Amendment and Equal Protection rights of the parties. ${ }^{133}$ The Court accepted the case, revisiting the question that has occurred repeatedly: "whether the First Amendment prevents a State from imposing its sales tax on only selected segments of the media." ${ }^{134}$ Unlike previous decisions answering this question, Justice O'Connor found in favor of the state in this case. ${ }^{135}$

In this case, the majority held that the tax is one of "general applicability" and, unlike the taxes in question in other cases, impacts "the sale of all tangible personal property and a broad range of services [emphasis added]."136 The opinion goes on to exhaustively list other goods and services subject to this taxation. ${ }^{137}$ This tax does not specifically target the press and threatens neither its First Amendment activities nor its role as a "watchdog of government."138 Most importantly, as in other cases where O'Connor has found for the state, the law is content neutral. The Court found that the "broad-based, content-neutral sales tax is (un)likely to stifle the free exchange of ideas." ${ }^{139}$ Once again, the idea that a state can regulate First Amendment activities, so long as the regulation is content-neutral and broadly applied, emerges from O'Connor's decisions.

\footnotetext{
${ }^{131}$ Ibid, at 442 .

132 Ibid.

${ }^{133}$ The parties included cable subscribers, a cable provider, and the Arkansas cable providers' trade organization.

${ }^{134}$ Ibid, at 444.

${ }^{135}$ See earlier discussion of Minneapolis Star \& Tribune Co. v. Minnesota Commissioner of Revenue, 460 U.S. 575 (1983), as well as Arkansas Writers' Project v. Ragland, 481 U.S. 221 (1987), among others.

${ }^{136}$ Ibid, at 447.

137 Ibid.

${ }^{138}$ Ibid, at 448-449.

${ }^{139}$ Ibid, at 453.
} 
Justice O'Connor and the Court continued to approve these content-neutral bans in $2000 .{ }^{140}$ The city of Erie, Pennsylvania enacted a ban on public nudity. Specifically, the ordinance made it a crime to "knowingly or intentionally appear in public in a "state of nudity." ${ }^{141}$ The respondent, a nude dancing establishment, would have been forced to have female dancers cover themselves with minimal undergarments to comply with the ordinance. ${ }^{142}$ The Pennsylvania Supreme Court, relying on previous Supreme Court precedent, reached two conclusions. First, it found that there was a clear precedent that nude dancing is "expressive conduct that is entitled to some quantum of protection under the First Amendment," although the act of being nude itself is not entitled to such protection. ${ }^{143}$ Second, the Pennsylvania Supreme Court found no binding precedent that could guide it in determining whether the law in question (a ban on willful public nudity) was content neutral. ${ }^{144}$ As a result, the majority of that court conducted their own examination and found the law in violation of Pap's A.M.'s expressive rights. The Pennsylvania Supreme Court did not find the ordinance more broadly unconstitutional. $^{145}$

The decision was challenged. The Supreme Court heard the case despite potential issues of mootness. ${ }^{146}$ Dismissing the issue of mootness, Justice O'Connor wrote the opinion for the Court. She found that the law itself was a legitimate use of power under the $O^{\prime}$ Brien test. $^{147}$ She accepted the argument that the ordinance was intended to prevent harmful secondary effects of

\footnotetext{
${ }^{140}$ City of Erie v. Pap's A.M., 529 U.S. 277 (2000).

${ }^{141}$ Ibid, at 284 .

${ }^{142}$ Ibid.

${ }^{143}$ Ibid, at 285.

${ }^{144}$ Ibid.

${ }^{145}$ Ibid, at $285-286$.

${ }^{146}$ Ibid, at 287-288.

${ }^{147}$ United States v. O'Brien, 391 U. S. 367 (1968). O'Brien established a test for whether a "sufficiently important governmental interest" exists to justify regulation of otherwise protected speech and conduct. Such conduct can be regulated if: the government has the constitutional power to regulate; if it furthers important government interests; if the interest is not intended to suppress expression; and if the restriction on alleged freedoms is "no greater than is essential to the furtherance of that interest" (in other words, narrowly tailored). at O'Brien, 376-377.
} 
willful nudity, defined as "the negative secondary effects associated with adult entertainment establishments." ${ }^{148}$ Deferring to the City of Erie about the possibility of secondary negative effects, Justice O'Connor found that the ordinance satisfied all four factors of the O'Brien test. ${ }^{149}$ Critically, she reasoned that the primary intent of the law was not to suppress expression, but instead is a narrowly-tailored prohibition intended to further a (legitimate and compelling) government interest. ${ }^{150}$ Once again, an effort by (local) government to regulate expressive conduct was upheld a content-neutral regulation related to an important government interest.

\section{b. The First Amendment's Religious Protections}

The First Amendment goes beyond simply the expressive protections that are so critical for citizen involvement in the democratic process. The development of an active, educated populace is also critical. Freedoms given are pointless unless used. Such a population is cultivated in part by federalism, as we have seen, giving citizens the ability to participate and learn at the lowest levels of government. Justice O'Connor made this point eloquently in her commencement address at Gettysburg College. Democracy requires more than freedoms, federalism (as Elazar suggests), and an active population. It also requires a developed civil society that produces citizens educated in and aware of democratic values. The First Amendment's religious protections are one of the ways in which our constitutional system helps to inculcate these values from its very inception.

Philosophers such as Amy Gutmann support this claim. Gutmann asserts that the value of religious diversity lies not simply in the freedom itself, but in the educational opportunity it provides for democratic citizens. Through the simple act of living next to people of other religions, we learn to accept the differences between us and as a result exist more easily as a

\footnotetext{
${ }^{148}$ City of Erie v. Pap's A.M., 529 U.S. 277 (2000), at 294-295.

${ }^{149}$ Ibid, at 297.

${ }^{150}$ Ibid, at 299-301.
} 
community. Further, the presence of persons with faiths different than our own helps us to inculcate democratic values in the schools, through education and exposure to different traditions. Citizens' learning these democratic values, in turn, develops civil society. ${ }^{151}$ Martha Nussbaum's "politics of humanity" moves beyond this with its claim that diversity - not only in religious terms - allows us to better imagine that another individual, different from ourselves, is also human, our neighbor, rather than simply an "other". ${ }^{152}$ This is just a small sampling of a broader point to be found in many corners of democratic theory and political philosophy: vibrant civil society plays a role in the democratic process as vital as that of voting or the free exchange of ideas. Civil society, then, is an important component in expressive democracy. The free practice of and restriction of state establishment of religions are an important part of developing civil society. As was argued previously, federalism helps to promote diversity. Religious diversity is no exception to this.

In the following section, we will examine Justice O'Connor's contribution to the relationship between the states and the First Amendment's religious freedoms. Whether because the states are less willing to venture into the business of regulating religion (not an entirely unlikely prospect), or because her opinions were less controlling in this area, the number of cases is fewer than those concerning expressive freedoms. Regardless of this fact, Justice O'Connor is true to form, deciding cases narrowly and with less regard to broad questions of constitutional law. As we will see, her essential reasoning in these cases is not dissimilar to that exhibited earlier: giving serious attention both to state interests and to the freedoms of those involved in the cases.

\footnotetext{
${ }^{151}$ Gutmann, Amy. Democratic Education. Princeton, NJ: Princeton University Press, 1999.

${ }^{152}$ Nussbaum, Martha. From Disgust to Humanity: Sexual Orientation and Constitutional Law. New York; Oxford: Oxford University Press, 2010.
} 


\section{i. Cases Decided Against the State}

Justice O'Connor's first decision balancing between the state and the First Amendment's religious protections came down in 1987. ${ }^{153}$ In 1983, the Board of Airport Commissioners for Los Angeles International Airport adopted a resolution that effectively prohibited individuals and groups from engaging in "First Amendment activities" at the airport. ${ }^{154}$ After a member of the group Jews for Jesus was asked to cease handing out literature at the airport, the individual and group filed suit challenging the policy. They argued that it violated both the state constitution and the First Amendment's ban on prohibiting the free exercise of religion; that it had been applied to them unfairly; and that it was "unconstitutionally vague and overbroad." 155 At the core of O'Connor's decision was the debate over the nature of the airport. One possible element of the decision could revolve around whether the airport was "a traditional public forum, a public forum creating by government designation, or a nonpublic forum." ${ }^{\prime 156}$ The Court's previous jurisprudence had determined that in traditional or government-designated public forums regulation of "First Amendment protections are subject to heightened scrutiny.",157

Justice O'Connor avoided the issue of the airport's exact nature as a forum. She stated that "because... the resolution is facially unconstitutional under the First Amendment overbreadth doctrine, we need not decide whether LAX is indeed a public forum." ${ }^{158}$ Using the overbreadth doctrine, the Court could consider not only the case before it, but the possible impacts of the statute in question beyond the immediate circumstances. ${ }^{159}$ The LAX policy restricting "First Amendment activities" restricted all such activity, not just what might disrupt operations at the

\footnotetext{
${ }^{153}$ Board of Airport Commissioners of the City of Los Angeles v. Jews For Jesus, Inc., 482 U.S. 569 (1987)

154 Ibid, at 571.

155 Ibid, at 572 .

${ }^{156}$ Ibid.

157 Ibid, at573.

158 Ibid.

${ }^{159}$ Ibid, at 574.
} 
airport. ${ }^{160}$ Finally, the vagueness of the policy was too broad for the Court. What kind of First Amendment activities covered was not specified, nor a reason why such a ban was necessary. ${ }^{161}$ This, combined with the fact that it banned all speech, left the statute overly broad and not narrowly tailored to meet the Board's ends. ${ }^{162}$ These facts in combination, we should now know, are enough for O'Connor to declare that it cannot survive the First Amendment challenge.

Whereas the previous case, in part, considered the free exercise of religion, the second case that allowed Justice O'Connor to balance religious freedoms against the state concerned the Establishment Clause. ${ }^{163}$ Students at Westside High School in Omaha, Nebraska requested permission in 1985 to form a Christian club at the school. ${ }^{164}$ Policy for the school district allowed students to form clubs with faculty sponsorship in line with school board policy and the district's mission statement. These policies included a provision that prohibited several types of organizations from forming, including religious organizations. ${ }^{165}$ Permission to form the Christian organization was denied by the administration, pursuant to policy. They explained that the club "would not or could not" have a faculty sponsor and that its formation would violate the Establishment Clause. ${ }^{166}$ In response, the students and their parents filed suit, alleging that the club's denial violated both the Equal Access Act and the students' "First and Fourteenth Amendment rights to free speech, association, and free exercise of religion."167

\footnotetext{
${ }^{160}$ Ibid, at 574-575.

${ }^{161}$ Ibid, at 575.

162 Ibid, at 576.

${ }^{163}$ Board of Education of the Westside Community Schools (Dist. 66) v. Mergens, 496 U.S. 226 (1990).

164 Ibid, at 232.

${ }^{165}$ Ibid, at 232. "Board Policy 5610 also provides that each club shall have faculty sponsorship and that "clubs and organizations shall not be sponsored by any political or religious organization, or by any organization which denies membership on the basis of race, color, creed, sex or political belief.""

166 Ibid, at 233.

${ }^{167}$ Ibid, at 233. "The Equal Access Act... prohibits public secondary schools that receive federal financial assistances and that maintain "limited open forum" from denying that "equal access" to students who wish to meet within that forum on the basis of the content of the speech at such meetings."
} 
Justice O'Connor's opinion for the majority agreed that the school district's prohibition violated the students' rights under the Equal Access Act. Finding that the Act requires schools with "limited public forums," defined as allowing one or more noncurricular groups to meet, to allow such students to conduct meetings without regard to the content of the meeting, she reasoned that the Act applied to Westside High School. ${ }^{168}$ She specifically interpreted "noncurricular group" to apply to any group not directly related to the "body of courses offered by the school."169 The school offered a number of clubs not directly related to its teaching functions, citing groups such as the Chess Club and the school's Peer Advocates group. ${ }^{170}$

Finally, while the decision rested primarily upon statutory interpretation, O'Connor reasoned that an "equal access" policy such as the one required by the Act (and applied to the school by the Court), does not violate the Establishment Clause. ${ }^{171}$ Such an open access policy is not constitutionally suspect for several reasons. First, government declining to censor speech or activities (such as the club in question would engage in) does not equate government endorsement. ${ }^{172}$ Second, such policies (as envisioned by the Equal Access Act) do not require attendance or sponsorship: students are free to conduct meetings during noninstructional time when attendance is not mandatory. ${ }^{173}$ Finally, the number of available clubs and the ability to create new clubs, should students choose to, vitiates any claim about an appearance of endorsement or preference of one religion over another. ${ }^{174}$ O'Connor wrote, "Under the Act, a school with a limited open forum may not lawfully deny access to a Jewish students' club, a

\footnotetext{
${ }^{168}$ Ibid, at $235-236$.

${ }^{169}$ Ibid, at 239.

${ }^{170}$ Ibid, at $245-246$.

${ }^{171}$ Ibid, at 250 .

${ }^{172}$ Ibid.

${ }^{173}$ Ibid, at 251.

${ }^{174}$ Ibid, at 252.
} 
Young Democrats club, or a philosophy club devoted to the study of Nietzsche." ${ }^{175}$ As a result, the Act does not violate the Establishment Clause, and the school's claim that their acceptance of such a club would do so was rejected by the Court. The majority declined to answer the Free Exercise and Free Speech claims. ${ }^{176}$

\section{ii. Cases Decided in Favor of the State}

In 1990, Justice O'Connor returned to the question of state governments' ability to tax in the context of the First Amendment's religious protections. ${ }^{177}$ California law required retailers to pay a $6 \%$ sales tax on in-state sales of "personal tangible property" and to collect from state residents a $6 \%$ use tax on such property purchased outside the State. ${ }^{178}$ The appellant Jimmy Swaggart Ministries, a non-profit incorporated in Louisiana, sold religious materials (including recordings, books, and other items) at events it held throughout the United States, including in California. ${ }^{179}$ The Ministry also conducted a mail-order business which sold to California residents. ${ }^{180}$ The California Board of Equalization conducted an audit, and informed the Ministry that it should register as a retailer pursuant to state law. The Ministry would then pay sales and use taxes on the aforementioned sales. ${ }^{181}$ The Ministry paid the taxes, but appealed for reconsideration and refund, arguing that such taxes violated the First Amendment. ${ }^{182}$ The Board of Equalization denied the appeals, and the Ministry filed suit in state courts. They argued that the imposition of the sales and use taxes violated both the Free Exercise and Establishment

\footnotetext{
175 Ibid.

176 Ibid, at 253.

177 Jimmy Swaggart Ministries v. Board of Equalization of California, 493 U.S. 378 (1990)

${ }^{178}$ Ibid, at 381 .

${ }^{179}$ Ibid, at 382.

${ }^{180}$ Ibid.

${ }^{181}$ Ibid, at 382-383.

182 Ibid, at 384.
} 
Clauses. ${ }^{183}$ The state courts affirmed the Board's decisions, and the case ultimately came before the Supreme Court. ${ }^{184}$

Writing for the Court, Justice O'Connor rejected the idea that the Free Exercise Clause was shelter for the Ministry from the tax in question. Previously, the Court had ruled that various taxes could not be applied to religious groups, such as in gaining a license, because such taxes operated as a "precondition to the free exercise of religious beliefs." 185 With much the same reasoning found in previous tax cases where O'Connor upheld taxes as not violating the First Amendment's expressive protections, she found the law was neutral to all sales. She concluded that the tax was general, "nondiscriminatory," and "that collection and payment of the tax violates appellant's sincere religious beliefs." ${ }^{186}$ Further, she reasoned that "the imposition of a generally applicable tax merely decreases the amount of money appellant has... any such burden is not constitutionally significant." ${ }^{187}$ The Establishment Clause claims were also rejected by the Court. As the tax is imposed generally, it does not require the state to inquire into the religious activities of the Ministry nor to regulate them. ${ }^{188}$ Nor does it regulate the content of the items that are sold or ask what items are "religious" and what are not, but simply treats the Ministry as a retailer. ${ }^{189}$ As a result, it does not represent the state enmeshing itself in the religious practices of the Ministry. ${ }^{190}$

\footnotetext{
183 Ibid.

184 Ibid.

${ }^{185}$ Ibid, at 387. See cases: Murdock v. Pennsylvania, 319 U.S. 105 (1943) and Follett v. McCormick, 321 U.S. 573 , 576 (1944)

186 Ibid, at 390.

${ }^{187}$ Ibid, at 391.

188 Ibid, at 396.

${ }^{189}$ Ibid, at 397.

${ }^{190}$ Ibid.
} 


\section{c. The Right to Privacy}

The final right considered in this exploration is the right to privacy, an area in which Justice O'Connor had a significant voice during her tenure on the Court. Scratching the surface of the right to privacy can yield much that shows how it too contributes to the development of civil society and the empowerment of the individual. The right to privacy has been invoked as a primary element in the expansion of sexual and reproductive freedoms in the late $20^{\text {th }}$ and early $21^{\text {st }}$ centuries. Martha Nussbaum connects the right to privacy and the choice between solidarity and diversity, especially in the context of sexual freedoms and diversity. ${ }^{191}$ Drawing on John Stuart Mill, she argues that diverse societies are marked by sufficient respect for "zones of seclusion and personal liberty."192 Such societies, according to Nussbaum, are free and healthy. ${ }^{193}$ Democracy flourishes in such conditions.

At least one attorney has observed that privacy is a $20^{\text {th }}$ century concept; it did not exist before and will not exist after. ${ }^{194}$ Changing technology may make this observation a truism. In spite of this assertion, we can see from precedents ranging from some of the earliest privacy decisions (e.g. Griswold v. Connecticut) to the most recent (e.g. Lawrence v Texas) that the right to privacy remains a valid, if controversial, legal concept. ${ }^{195}$ To see its implications in the ability of modern Americans to live and operate as empowered individuals in society - its role as a refuge for liberty - we need look no farther than the joint decision in Planned Parenthood $v$. Casey. As discussed in the introduction, Justice O’Connor joined her colleagues in that decision in writing that a generation of men and women had planned their lives - their very participation in political, economic, and civil life - around the essential holding of Roe v. Wade. The right to

\footnotetext{
${ }^{191}$ Ely0, p. 55.

192 Ibid, pp. 58-59.

193 Ibid, p. 59.

${ }^{194}$ Conversation with Grace Suarez, a San Francisco criminal defense attorney.

195 See cases: 381 U.S. 479 (1965) and 539 U.S. 558 (2003).
} 
privacy may not have been envisioned by the Framers of the Constitution, but it has become an essential part of life for modern Americans and their ability to participate in civil society.

The following section will follow the same approach as the previous analysis of the First Amendment's expressive and religious protections. The cases that will be analyzed, which concern reproductive and sexual freedom, have been discussed in extensive detail in many forums, both scholarly and non-scholarly. The broad contours and Justice O'Connor's contributions to them, in majority, concurrence, or dissent, will be described. Attention will be given first to reproductive freedoms, and then to sexual freedoms, in recognition of their chronological development as legal issues.

\section{i. Reproductive Freedoms}

Before her tenure on the Court, Justice O'Connor's attitude toward reproductive freedoms was unclear. Her testimony in her confirmation hearings was intentionally vague. As a state legislator, she supported Arizona's repeal of abortion restrictions and opposed a resolution calling for Congress to take action to restrict abortion in the wake of Roe v. Wade. ${ }^{196}$ Her nomination was opposed by some pro-life activists who were convinced that O'Connor would support abortion rights. ${ }^{197}$ When she was in the witness seat before the Senate Judiciary Committee, O’Connor remained vague about how precisely she would vote on abortion issues.

She made her personal feelings clear when she stated, "...for myself, [abortion is] simply offensive to me. It is something that is repugnant to me and something in which I would not engage."198 She made it very apparent that whatever her personal feelings on abortion (and any other subject), they should not and would not inform her decisions as a judge. ${ }^{199}$ While the

\footnotetext{
${ }^{196}$ Biskupic, pp. 58-59.

${ }^{197}$ Ibid, pp. 94-96.

198 Ibid, p. 125.

199 Ibid, p. 60.
} 
senators continued her questioning, she echoed these themes again and again, with one added caveat. The former state legislator reminded Congress that in any policy question, it was the duty of the legislature to draw the lines of what is acceptable, keeping in mind relevant case law (such as Roe v. Wade). ${ }^{200}$ Biskupic summarizes O'Connor's position on abortion at her confirmation testimony as effectively saying "it is up to elected lawmakers to decide when abortion should be allowed." ${ }^{201}$ It will become clear that when she suggests lawmakers decide when abortion should be allowed, she has confidence - as always - in state legislators to do so.

In a series of decisions spanning the entirety of her tenure on the Court, Justice O'Connor became the most influential justice on abortion issues. She was not immediately in a controlling position, however. Her first vote cast on the abortion issue was in the minority, in dissent to a decision made in $1983 .{ }^{202}$ The City of Akron, Ohio passed an ordinance with a number of abortion regulations. ${ }^{203}$ It included requirements that "all abortions be performed after the first trimester... in a hospital"; that parents be notified before abortions are performed on unmarried minors; that physicians "make certain specified statements" in order to obtain "truly informed consent"; that any woman seeking an abortion wait 24-hours between giving consent and undergoing the procedure; and that fetal remains "be disposed of in a humane and sanitary manner." ${ }^{204}$

All five of the provisions listed were struck down as unconstitutional by the majority decision written by Justice Lewis Powell. In her dissent, Justice O'Connor made no secret of her criticism of Roe. She called the trimester framework adopted by the majority in that decision an "unworkable method of accommodating the conflicting personal rights and compelling states

\footnotetext{
${ }^{200}$ Ibid, p. 125.

${ }^{201}$ Ibid, p. 94.

${ }^{202}$ City of Akron v. Akron Center for Reproductive Health, Inc., 462 U.S. 416 (1983).

${ }^{203}$ Ibid, at 422.

${ }^{204}$ Ibid, at $422-424$.
} 
interests that are involved in the abortion context." ${ }^{205}$ Further, she makes clear that she believes medical advances had pushed technology beyond the trimester-framework and it would not be sustainable as advances continued. ${ }^{206}$ Further, and most importantly, this is the first case where O'Connor had the opportunity to bring forward (even in dissent) the "undue burden" standard that would become so important to her in the future. ${ }^{207}$ The undue burden standard, at this point, simply suggested that if a regulation was not found to place such a burden on the fundamental right to an abortion, then it should be subject merely to rational basis review. ${ }^{208}$

Justice O'Connor found herself in dissent again in a 1986 case coming out of Pennsylvania. $^{209}$ The Court considered a Pennsylvania law that placed restrictions on abortion in the form of a waiting period and a requirement that providers obtain "informed consent", which included a state-mandated description of the state of the fetus. ${ }^{210}$ Justice Blackmun wrote the majority opinion, which found that such mandated speech unnecessarily invaded the patientdoctor relationship and "requires the dissemination of information that is not relevant to consent, and, thus, it advocates no legitimate state interest." ${ }^{211}$ He concluded the decision with its most essential holding, that "a woman's right to make [the] choice [to end her pregnancy] is fundamental." 212 O’Connor echoed her own 1983 dissent. Once again, she criticized the trimester-framework that guided the Court's and asserted the "undue burden" standard used in

\footnotetext{
${ }^{205}$ Ibid, at 454 .

206 Ibid, at 458.

${ }^{207}$ Ibid, at 453.

${ }^{208}$ Ibid, at 453.

${ }^{209}$ Thornburgh, Governor of Pennsylvania v. American College of Obstetricians and Gynecologists, 476 U.S. 747 (1986)

${ }^{210}$ Ibid, at 761-762. See also: Biskupic, p. 117.

211 Ibid, at 763 .

212 Ibid, at 772A.
} 
earlier cases. ${ }^{213}$ Her dissent was one among several, but provided another step along her path toward her future critical role in reproductive rulings.

The first major sea-change in abortion rulings came in 1989, when Justice O'Connor joined now-Chief Justice William Rehnquist in a majority opinion concerning abortion regulations coming from Missouri. The case was Webster, Attorney General of Missouri v. Reproductive Health Services. ${ }^{214}$ The regulation was adopted by Missouri in 1986 and contained several provisions. It required that Missouri law be interpreted to provide the unborn with the same rights as other persons; that government-employed doctors refuse to abort fetuses they considered viable; prohibited the use of state employees, facilities, or funds to encourage or perform abortions (with an exception for the life of the mother). ${ }^{215}$ It also imposed a requirement that physicians perform viability tests if the woman appeared to be "at least twenty weeks pregnant."216 Justice Rehnquist, writing for a plurality of justices, found that none of the provisions outlined above were unconstitutional. According to Rehnquist, there was no affirmative right to government aid in abortion procedures. ${ }^{217}$ Nor was there any issue with the counseling $^{218}$ or viability testing requirements of the law. ${ }^{219}$ The broader impact of the decision meant that states were thus free to regulate abortions.

Justice O’Connor concurred with, but did not join, Rehnquist's opinion. Writing separately, she did not echo her previous decisions about the problematic nature of Roe. ${ }^{220}$ Instead, she focused first on the ability of the states to regulate abortion. She did not find the

\footnotetext{
${ }^{213}$ Ibid, at 814-815.

214492 U.S. 490 (1989).

${ }^{215}$ Ibid, at 501.

${ }^{216}$ Biskupic, at 219.

${ }^{217}$ Ibid, at 507-509.

${ }^{218}$ Ibid, at 512

${ }^{219}$ Ibid, at 514-515.

${ }^{220}$ Ibid, p. 230.
} 
provisions of the Missouri law to be overly burdensome to women. ${ }^{221}$ She wrote that "the performance of examinations and tests... to [determine] whether a fetus is viable, when viability is possible, and when it would not be medically imprudent to do so, does not impose an undue burden on a woman's abortion decision.,"222

More important, though, was the change that her concurrence represented. Biskupic argues that this decision "was a pivot that would set her in another direction [on abortion]."223 This change was her desire to affirm the essential holding of Roe. This is clear from her language in her concurrence: "When the constitutional invalidity of a State's abortion state actually turns on the constitutional validity of Roe v. Wade, here will be time enough to reexamine Roe. And to do so carefully."224 This is no small part a response to the plurality's desire - and Justice Scalia's insistence - to revisit Roe. ${ }^{225}$

Justice O'Connor's changing position on abortion is also apparent in a case concerning a law from Minnesota, Hodgson v. Minnesota. ${ }^{226}$ The statute concerned the access of minors to abortions. Under the statute, minors could not receive abortions until two days after both parents had been notified. Exceptions existed in the statute for medical emergencies, victims of abuse, and for judges to allow "mature" minors to bypass notification requirements. ${ }^{227}$ The decision was split, with multiple concurrences and dissents coming from the justices. The general holding, however, ruled that the two-parent notification was an "oddity" among such requirement provisions. ${ }^{228}$ Finding that no other state with such notification requirements required both parents to be included, Justice Stevens' majority opinion found the provision

\footnotetext{
221 Ibid.

222 Ibid.

${ }^{223}$ Ibid, p. 231.

${ }^{224}$ Ibid, p. 230.

${ }^{225}$ Ibid, at 521.

${ }^{226} 497$ U.S. 417 (1990).

${ }^{227}$ Ibid, at 422-423.

${ }^{228}$ Ibid, at 454.
} 
unrelated to any compelling state interests and overturned the requirement. ${ }^{229}$ The Court upheld the law with the judicial bypass provision, however. Justice O'Connor joined the majority which rejected the two-parent provision, but also joined the other conservatives on the Court in accepting the Court of Appeals' ruling that the bypass procedure preserved the law. ${ }^{230}$ Justice O'Connor had begun to move away from her criticism of Roe v. Wade in the Webster decision, and would come full circle in 1992. We have already examined the decision in Planned Parenthood v. Casey in some detail in the introduction. This decision represented the “opportunity for O’Connor to refine her approach to abortion rights that she had been developing since the 1983 Akron case." ${ }^{„ 231}$ The case concerned a challenge to broad abortion restrictions adopted by Pennsylvania in 1988 and $1989 .{ }^{232}$ The Pennsylvania statutes contained several provisions similar to ones we have already seen in previous cases. These included a requirement that women give informed consent 24 hours before a procedure; that she be provided "certain information" before an abortion; and that at least one parent provide consent before a minor can undergo an abortion (with a judicial bypass for exceptional circumstances). ${ }^{233}$ Unlike other states, Pennsylvania also adopted a provision that required "a married woman seeking an abortion [to sign] a statement indicating that she has notified her husband of her intended abortion." 234

The controlling opinion in this case was, as we have seen, not the work of a single justice, but O'Connor's hand can be seen throughout the opinion. The plurality of Justices O'Connor, Kennedy, and Souter affirmed the Court of Appeals' ruling that upheld all of the Pennsylvania

\footnotetext{
${ }^{229}$ Ibid, at 455 .

${ }^{230}$ Ibid, at 458 .

${ }^{231}$ Biskupic, p. 270.

${ }^{232} 505$ U.S. 833 (1992), at 844.

${ }^{233}$ Ibid.

${ }^{234}$ Ibid.
} 
provisions "except for the husband notification requirement.", ${ }^{235}$ This included an adoption of the undue burden standard, which was further clarified by the justices. According to the plurality, "an undue burden exists, and therefore a provision of law is invalid, if its purpose or effect is to place a substantial obstacle in the path of a woman seeking an abortion before the fetus attains viability." ${ }^{236}$ They reaffirmed the central holding of Roe $v$. Wade, but "reject[ed] the rigid trimester framework" it adopted. ${ }^{237}$ In its place, they held that states, because of their "profound interest in potential life" may "take measures to ensure that the... choice is informed." ${ }^{238}$ Measures "designed to advance this interest will not be invalidated as long as their purpose is to persuade the woman to choose childbirth over abortion." States could "enact regulations to further the health or safety of a woman seeking an abortion." ${ }^{239}$ All such measures would be held to the undue burden standard adopted and expanded herein, but states were allowed to regulate abortion more freely than ever before. In place of the trimester approach of Roe, a combination of undue burden and viability would take its place.

The only provision of the Pennsylvania law struck down by the plurality was the husband notification requirement. This rejection clearly shows O'Connor's hand. The justices wrote in their opinion:

Section 3209 embodies a view of marriage consonant with the common-law status of married women but repugnant to our present understanding of marriage and of the nature of the rights secured by the Constitution. Women do not lose their constitutionally protected liberty when they marry. The Constitution protects all individuals, male or female, married or unmarried, from the abuse of governmental power, even where that power is employed for the supposed benefit of a member of the individual's family. These considerations confirm our conclusion that $\$ 3209$ is invalid.

This line of thought regarding the husband notification requirement comes directly from O'Connor's questioning during oral arguments. She questioned the Attorney General of

\footnotetext{
${ }^{235}$ Ibid, at 879 .

${ }^{236}$ Ibid.

${ }^{237}$ Ibid, at 879 .

${ }^{238}$ Ibid, at 878 .

${ }^{239}$ Ibid.
} 
Pennsylvania vigorously about the requirement. The tone of her questions and responses to his arguments made one thing abundantly clear: O'Connor was skeptical of the requirement as an unequal standard. ${ }^{240}$ Such a requirement falls only on one class of women seeking abortions: married women. As the language above, as well as her questioning during oral arguments makes clear, O’Connor had no patience for such paternalistic thinking and brought that reasoning with her to the opinion. The husband notification requirement, in essence, placed an undue burden on a married woman's right to seek an abortion because it was a government regulation falling unduly on one class. This is a line of thought we have seen in previous cases, and that we will see again when we consider sexual freedoms.

Casey represented a victory for Justice O'Connor's jurisprudence. The legal standard she had been developing for a decade transitioned, with the country and the court, from dissent to precedent. The undue burden standard and deference to the states she had articulated over her tenure on the Court was accepted by a plurality, and became the controlling position of the Court for later decisions on abortion by the Court. Roe v. Wade's essential holding would survive, but tempered by the new holding forged by O'Connor and two other centrist jurists. Her last opinion on abortion, concurring in Stenberg v. Carhart, would contain the same hallmarks. ${ }^{241}$ The majority used the undue burden standard to overturn a partial-birth abortion ban in Nebraska which did not contain a provision for the mother's health. ${ }^{242}$ O'Connor, in her usual fashion, concurred in the decision, suggesting a path state for state legislatures that would allow them to craft a ban consistent with the Court's abortion case law. ${ }^{243}$

\footnotetext{
${ }^{240}$ Biskupic, p. 268.

${ }^{241}$ Ibid, p. 275.

${ }^{242}$ Ibid.

${ }^{243}$ Ibid, pp. 275-276. O'Connor's recommendation for state legislatures involved the inclusion of medical exceptions for the health of the mother. For her, such ordinances could pass the undue burden standard.
} 


\section{ii. Sexual Freedoms}

Justice O'Connor's position on the constitutional rights (or lack thereof) of homosexuals has been less controlling than that of Justice Kennedy, who has written most of the majority decisions on that subject in the past twenty years. Nevertheless, in this area as well, her approach evolved over time. During her tenure, the Court issued four major decisions concerning gay rights, as opposed to its numerous abortion decisions. This is due in no small part to the evolution of the gay rights movement compared to the abortion debate. Abortion rights were a part of the women's rights movement, which had taken place over the late $19^{\text {th }}$ and early $20^{\text {th }}$ centuries in America. The gay rights movement as we know it only began to coalesce in the early 1950s, exploded with the Stonewall Riots in 1969, and did not begin to see actual victories until the past quarter century. Much of the constitutional debate about gay rights has yet to be written, and Justice O'Connor's voice will only be heard through her precedential impact.

During her confirmation hearings, O’Connor was questioned about her judicial philosophy concerning the rights of homosexuals. She was asked by Senator Denton if she believed that there were "any constitutional limits on laws which might be passed by a State or the Federal Government forbidding homosexuality, homosexual practices, or limiting the rights of homosexuals because of their sexual deviance."244 Her response, as most others, was vague. She asserted that the question of homosexuality in constitutional law was, "in one word, unsettled." ${ }^{245}$ Citing some previous case law, she suggested that such case law remained open

\footnotetext{
${ }^{244}$ Confirmation testimony of Sandra Day O'Connor, p. 247.

${ }^{245}$ Ibid.
} 
and was likely a question the Court would face in the future. ${ }^{246}$ She made no substantive statements in response to Denton's questioning, however.

The first case concerning the constitutional rights of homosexuals was Bowers $v$. Hardwick. $^{247}$ That decision concerned a Georgia law classifying homosexual sodomy as illegal. $^{248}$ In the majority opinion, which O'Connor joined, the Court declined to answer questions about the "wisdom or desirability" of sodomy laws; rather, the Court framed the question as whether there was a constitutional right to engage in homosexual activity. ${ }^{249}$ The Court decided that there was no such right to be found in the Constitution or in prior case law. ${ }^{250}$ O'Connor did not write in this decision, and it is not clear how controlling she was in the opinion. Rather, her friend and mentor Justice Lewis Powell was the controlling vote in this case. $^{251}$

The Court did not revisit gay rights in any substantive fashion again until the 1990s. Its next decision was Romer v. Evans in $1996 .^{252}$ In that decision, the majority struck down a Colorado amendment to the state constitution that would have prevented any municipality or county in the state from taking any action to recognize gay and lesbian citizens as a protected class of persons and repealed any such laws already extant. ${ }^{253}$ O'Connor voted with the majority to strike down the law, in the first major gay rights decision written by Justice Kennedy. She did so without comment. It is clear from her attitude toward the husband notification requirement at issue in Casey that her attitude toward legal restrictions that fall unfairly on one class of persons

\footnotetext{
${ }^{246}$ Ibid.

247478 U.S. 186 (1986).

${ }^{248}$ Ibid, at 188-189.

${ }^{249}$ Ibid, at 190.

${ }^{250}$ Ibid, at 192-195.

${ }^{251}$ See Lazarus, Edward. Closed Chambers: The Rise, Fall and Future of the Modern Supreme Court. New York: Penguin Books, 1999. p. 386.

252517 U.S. 620 (1996).

${ }^{253}$ Ibid, at 623-624.
} 
had become suspect in her mind. Four years later, she joined the majority in upholding the rights of the Boy Scouts of America (and, by extension, other public organizations) to exclude certain persons from membership based on criteria set by the groups. ${ }^{254}$

O'Connor's only written opinion on the constitutional nature of gay rights came with the Court's landmark decision, Lawrence v. Texas. ${ }^{255}$ The case involved violation of Texas' antisodomy law by two consenting adult males. ${ }^{256}$ The Court considered three questions in this case: one, whether the convictions under Texas' law violated the Equal Protection Clause of the Fourteenth Amendment; two, whether their convictions violated their liberty and privacy rights under the Due Process Clause of the same; and three, whether Bowers v. Hardwick should be overturned. ${ }^{257}$ The majority focused on the Due Process Clause, identifying a liberty interest that protects consensual sexual behavior between adults. They found that Bowers missed the point in framing the question about a right to engage in homosexual sodomy. ${ }^{258}$

The right protected is instead the right to engage in intimate and personal conduct. Kennedy wrote, "When sexuality finds overt expression in intimate conduct with another person, the conduct can be but one element in a personal bond that is more enduring. The liberty protected by the Constitution allows homosexual persons the right to make this choice." 259 The majority thus struck down sodomy laws and overturned Bowers, saying, "Bowers was not correct when it was decided, and it is not correct today. It ought not to remain binding precedent.

Bowers v. Hardwick should be and now is overruled." ${ }^{260}$

\footnotetext{
${ }^{254}$ Boy Scouts of America v. Dale, 530 U.S. 640 (2000).

${ }^{255} 539$ U.S. 558 (2003).

${ }^{256} \mathrm{Ibid}$, at $562-563$.

${ }^{257}$ Ibid, at 564 .

${ }^{258}$ Ibid, at 567-568.

${ }^{259}$ Ibid, at 567 .

${ }^{260} \mathrm{Ibid}$, at 568 .
} 
Justice O'Connor concurred in the decision to strike down the Texas sodomy laws, but on different grounds. First, she did not participate in the decision to overturn Bowers. Second, she did not join the majority in using due process to overturn the convictions and sodomy laws; instead, she relied on the Equal Protection Clause. ${ }^{261}$ Her analysis turned on the fact that the Texas provision and similar laws were animated by a moral disapproval that was unacceptable in making laws that target one group of people. ${ }^{262}$ Such moral disapproval cannot be a compelling government interest, and thus the law cannot survive even rational basis review through the Equal Protection Clause. ${ }^{263}$ She further observed that she was confident that a sodomy law "that is neutral both in effect and application" would "not long stand in our democratic society."264 Quoting Justice Jackson, she grounded her belief in the democratic process in the idea that "there is no more effective practical guaranty against arbitrary and unreasonable government than to require that the principles of law which officials would impose upon a minority be imposed generally." 265

Her refusal to look back and overturn Bowers is unsurprising. O'Connor was a woman who rarely looked back; her disposition was naturally pragmatic and forward looking, her jurisprudence narrow. O'Connor was not unwilling to revisit precedents, but argued that doing so must be done cautiously. ${ }^{266}$ Her admonition that there would be time enough to do so regarding Roe v. Wade when necessary is proof enough of that. We can see that despite her desire to preserve Bowers, she was willing to move past that point as a jurist. From the point of Casey onward, O'Connor's attitude toward the right to privacy seems to have evolved. The

\footnotetext{
${ }^{261}$ Ibid, at 579 .

${ }^{262}$ Ibid, at 581 .

${ }^{263}$ Ibid, at 583 .

${ }^{264}$ Ibid, at 584-585.

${ }^{265} \mathrm{Ibid}$, at 585 .

${ }^{266}$ Huhn, Wilson Ray. "The Constitutional Jurisprudence of Sandra Day O'Connor: A Refusal to "Foreclose the Unanticipated”.” Akron Law Review, Vol. 39 (2006). pp. 42-43.
} 
ability to participate fully in civil and political life was impeded by discriminatory laws that unduly burdened one group over all others. O'Connor emerged as a champion of individuals entering society, however unintentionally. 


\section{Analysis}

Having described a long series of facts and cases, it is now incumbent upon us to thread them together. The question must be asked: what connects these cases? I began by quoting the plurality opinion in Casey, which declared that "liberty finds no refuge in a jurisprudence of doubt." I argued then that the plurality rejected the uncertainty that overturning a precedent that established a liberty on which men and women had come to depend in favor of a jurisprudence of skepticism. The justices balanced the interests of the state and the individual with a skeptical, rather than a doubtful, eye, and preserved that liberty while allowing for the states to have a voice in the exercise of the identified right. A jurisprudence of skepticism and the inquiry into motives and facts it requires is certainly part of O'Connor's work, as we have seen. But there is more to this analysis than that alone.

Liberty is not only threatened by a jurisprudence of doubt that intends to unnecessarily disturb the framework of fundamental rights on which people plan their lives. Liberty is also threatened by a jurisprudence of naiveté. By this, I mean the assumption that government will always accomplish the best ends. Even democracy fails in this regard despite the best intentions of its framers, leaders, and citizens. We can look back to the arguments made in the Federalist papers suggesting that the federalist system would be its own guarantee of liberty, with state and national government checking one another and see their failure all too clearly. That faulty assumption was carried into case law by Barron v. Baltimore and remained binding for a century.

The man so rightly regarded as the father of our modern judicial system seems, to modern eyes, to have missed the point of the Bill of Rights. Writing for a typically unanimous Court, 
Chief Justice Marshall declared, "The constitution was ordained and established by the people of the United States for themselves, for their own government, and not for the government of the individual states." ${ }^{267} \mathrm{He}$ further reasoned that, "Had the framers of these amendments intended them to be limitations on the powers of the state governments, they would have imitated limitations on the powers of the state governments, they would have imitated the framers of the original constitution, and have expressed that intention." ${ }^{268}$ State governments were thus unlimited by the Bill of Rights until the rights were incorporated through the Fourteenth Amendment, a process begun in the late $19^{\text {th }}$ century and that made its way into precedent over the course of the $20^{\text {th }} .269$

Incorporating various provisions of the Bill of Rights does not settle the law around them, however. A Supreme Court decision asserting that the right to keep and bear arms does not anticipate every challenge that may come before the courts in the future. ${ }^{270}$ Once a controversy arises that merits the Court incorporating a right to the states, it opens the door to further controversies and further cases. ${ }^{271}$ These controversies allow the Court to expand, narrow, or distinguish their case law and develop precedent to the point that it can govern the states and the lives of citizens. Very few issue areas are ever settled law; even less so when they concern rights definitions that are only decades old, at best.

What we see at work in the cases above is an important aspect of the Rehnquist Court's federalist revival. It has already been established that Justice O'Connor was an important, leading voice in that effort. We have also seen that she was not as willing as the other

\footnotetext{
26732 U.S. 243 (1833), at 247

268 Ibid, at 250.

${ }^{269}$ The first justice to argue that the Fourteenth Amendment applied the Bill of Rights to the states was Justice John Marshall Harlan I. He first did so in his dissent in Hurtado v. California, 110 U.S. 516 (1884).

${ }^{270}$ McDonald v. Chicago, 561 U.S. __, 130 S.Ct. 3020 (2010)

${ }^{271}$ Such cases arise rarely. The last case in which the Court incorporated any provision of the Bill of Rights was District of Columbia v. Heller, 554 U.S. 570 (2008), the first time in almost 50 years that the justices had done so.
} 
conservative justices in retrenching the states as the leading force in American politics in every issue. Webster v. Reproductive Health Services is the perfect example of this distinction between O'Connor and her colleagues. The rest of the majority in that decision wanted to revisit, and even overturn, Roe v. Wade. O'Connor's decision to urge the Court to revisit Roe only when (if!) it was necessary preserved the precedent, despite the urgings of her colleagues Rehnquist, Scalia, and others. ${ }^{272}$ After decades of states' rights being a discredited concept, they were given new life by the Rehnquist Court - but with a new understanding. The country now understood that the assumption of the Framers and the reasoning of Chief Justice Marshall could no longer survive, and the Court - led, I would argue, by O'Connor - adopted this reasoning.

This is where Justice O'Connor becomes the fulcrum on which states' rights swing (and another reason why the Rehnquist Court is so rightly termed the O'Connor Court). She, more than the other conservative jurists, seems to have been skeptical of the states when it came to regulating the rights of individuals and their ability to participate in public, civil, and economic life. In decisions ranging from the ability of the state to tax critical parts of press and religious activities to life-altering decisions about pregnancy and relationships, Justice O’Connor approached the asserted interests of the state in controlling these activities with a jurisprudence of skepticism. In many cases, she found state regulations of such rights to be perfectly acceptable. This is not surprising; everything about her background and the empirical evidence of her career suggest that she would be and was friendly to the states.

But not always: when individuals and their rights were taxed, targeted, or regulated in a way that prevented their participation in life on an equal level as everyone else, O'Connor found the states' interests wanting and their arguments lacking. This same logic applied whether she was leading the push for repeal of Arizona's laws limiting women's working hours as a state

${ }^{272}$ Biskupic, pp. 224-225. 
senator or whether she was leading the Supreme Court in striking down a provision that unduly burdened the right of only married women to exercise their right to an abortion. O'Connor was not a liberal jurist who would vote at every turn to expand rights at any cost, but she was a skeptic. She rejected both a jurisprudence of doubt (which need be labeled neither liberal nor conservative) and a jurisprudence of naiveté. Her pragmatic approach to life informed her pragmatic approach to the act and art of judging, and it allowed her the luxury of influencing so much of the Court's activity.

This is the redefinition of federalism to incorporate the new limits of the Constitution and case law. Renewed as states' rights may be as practice and federalism may be as theory, those applying these rights must acknowledge the emerging truths of modern life that the Court had no choice but to ignore. Ours is a society that has become acclimated to diversity, which the Court has played no small role in fostering. Attempts to move the law back to a point where such matters were left to the state would be dangerously regressive. O'Connor avoided such regression in part by avoiding the sweeping constitutional answers some of her fellow justices were more comfortable with. The incremental, fact-based approach - the judicial minimalism that O'Connor's friend and mentor Justice Powell advocated - did not provide easy answers for anyone looking to the Court for such, but they did provide answers over time.

Cass Sunstein sets up an excellent frame of reference for this discussion. Rather than providing rules, Sunstein argues, O’Connor sought and developed standards of law. ${ }^{273}$ This was a function of the minimalist approach she adopted and shared with Powell. Biskupic cites Sunstein as saying that "the minimalism embraced by O'Connor could foster democracy, "not only in the sense that it leaves issues open for democratic deliberation, but also and more fundamentally in the sense that it promotes reason-giving and ensures that certain important

\footnotetext{
${ }^{273}$ Biskupic, p. 287.
} 
decisions are made by democratically accountable actors.",274 I go one step farther than Sunstein, however.

Whereas he considers the whole of O'Connor's career, which was certainly marked by deference to elected bodies whenever possible, I have focused specifically on the relationship between the state and the individual. In this context, O'Connor was guided not only by the desire to allow the states to settle issues democratically (local solutions for local problems), but, I argue, was also guided by the principles seen in her speech at Gettysburg College. It is not enough for O'Connor that decisions are made democratically - individuals must also be able to participate in the full range of political and civil life so that they, in every possible sense, can be involved in developing and making those decisions.

This is how citizens become involved in their government and, ultimately, how new policies are developed, debated, and accepted or rejected. The full range of rights available to Americans must be available to all Americans, unless some compelling government interest allows the states (or, it can be supposed, the federal government) to regulate these rights. If they do regulate these rights, it must be in a general fashion that does not discriminate unnecessarily or unreasonably. Any discriminatory regulation on the rights of Americans becomes suspect without sufficient justification. This is the essence of expressive democracy and its relationship to federalism: the government, state or federal, must be constrained in its ability to unreasonably restrain or suppress expression and diversity of choice. Justice O'Connor's balance between the states and the rights of the individual ultimately furthered this distinction.

O'Connor's jurisprudence in this realm is true to her background. She has a basic belief in equality of opportunity, rather than of outcome, that has its roots as far back as her girlhood on the Lazy B Ranch. Her mother was a college-educated woman in a time when this was a rarity;

\footnotetext{
${ }^{274}$ Biskupic, pp. 287-288.
} 
her father railed against the New Deal and believed firmly in the power of individual initiative. It is true that O'Connor was a centrist rather than an archconservative. Still, she carried these lessons from her youngest days into her political beliefs and her jurisprudence. The examples cited above - her work on women's rights as a legislator and abortion as a jurist - make this plain. O'Connor's belief in the ability of the individual to make their own way in civil and political life translated into a jurisprudence that required that the doors to doing so be open to all individuals. Our federalist system, with its democratic traditions and constitutional limits, provided the best opportunity for this.

This is, of course, only one possible interpretation of Justice O'Connor's jurisprudence in this area. The particular combination of cases and rights presented here could be interpreted in other ways, though I believe I have presented a more-than-reasonable account of their impact and of O'Connor's evolution in them. I will spare a few pages before concluding to apply the ideas of two important theories of constitutional interpretation to the cases outlined above. As promised, I will consider this vein of jurisprudence first through the lens of Herbert Wechsler's "neutral principles" of constitutional law. ${ }^{275}$ Second, I will examine it through the work of John Hart Ely's theory of interpretation presented in his book, Democracy and Distrust. ${ }^{276}$

a. Wechsler's Neutral Principles

Professor Wechsler delivered his famous lecture in 1959. His lecture was given in response to a speech in the same series a year before by Judge Learned Hand. This lecture, entitled "Toward Neutral Principles of Constitutional Law," was the beginning of a new phase in debate about the nature of constitutional interpretation. Wechsler discussed at length the need for the Court to act in a consistent fashion, rather than ad hoc. He describes ad hoc evaluation of cases as "the

\footnotetext{
${ }^{275}$ Wechsler, Herbert. Toward Neutral Principles of Constitutional Law. 73 Harv. L. Rev. 1 (1959). ${ }^{276}$ Ely.
} 
deepest problem of our constitutionalism, not only with respect to judgments of the courts but also in the wider realm in which conflicting constitutional positions have played a part in our politics." 277 Wechsler suggests that instead of engaging in what might be alternately termed the common law approach, the Courts should instead identify and articulate "neutral principles" that "transcend the case at hand." 278

He seeks principled decisions from the courts, defined thus: "A principled decision, in the sense I have in mind, is one that rests on reasons with respect to all the issues in the case, reasons that in their generality and their neutrality transcend any immediate result that is involved."279 When he speaks of such principles, he is criticizing the type of ad hoc reasoning that many believe was at work in Brown v. Board, which he argues was decided wrongly. He does not seem to disagree with the result of Brown, but rather the Court's reasoning. ${ }^{280}$ For Wechsler, the decision was about the freedom to associate, a prime example of a neutral principle that could be articulated and applied by the courts without the need to reach a conclusion and then justify the reasoning in what Ely calls a "connect-the-dots exercise.",281

Armed with the knowledge of Wechsler's proposed theory of interpretation, we must then ask: how well does this theory explain Justice O'Connor's jurisprudence, especially the aspects of it considered here? The answer, I am afraid, is not very well. This has more to do with the weaknesses of Wechsler's argument than O'Connor's judging. It is not difficult to demonstrate why. Wechsler declares that the courts must be principled, meaning that they should seek and apply neutral principles. Based on the text of the Constitution, the courts should

\footnotetext{
${ }^{277}$ Ibid supra note 262, p. 12.

${ }^{278}$ Ibid, p. 17.

${ }^{279}$ Ibid, p. 19.

${ }^{280}$ This is similar to the criticism of Roe v. Wade made by Justice Ruth Bader Ginsburg. For more information, see Ginsburg, Ruth Bader. "Speaking in a Judicial Voice: Reflections on Roe v. Wade." Judges on Judging. David O'Brien, Ed.. Washington, D.C.: CQ Press, 2008.

${ }^{281}$ Ibid supra note 262, p. 34. For Ely's description, see note 263, p. 54.
} 
identify the freedom to associate and apply that principle consistently, in line with the facts of the case. This seems simple enough in theory. In practice, however, it becomes more difficult. While some provisions of the Constitution are very clear (the President must be at least 35 years old; the House of Representatives will be elected every two years; the Supreme Court has original jurisdiction over cases involving ambassadors), the meaning of much of the Constitution is unclear.

As a result of the vagueness of the text, we may well be able to identify a right to associate, or to bear arms, or for the accused to confront witnesses against him, but that is all that we are able to extract from the text. Any other meaning is imported, either from the facts of the case, precedent, or from the very act of judging. Wechsler quotes Justice Holmes (and here I paraphrase the justice) as saying "a constitution... embodies relatively fundamental rules of right, as generally understood by all English-speaking communities." ${ }^{\text {282 }}$ This view is heavily tinged with Wechsler's other caveats, which plainly urge judicial restraint. It is no wonder that he quotes Holmes, the great advocate of judicial restraint. Wechsler states clearly that judges must abstain from judging when "the Constitution has committed the determination of the issue to another agency of government than the courts. ${ }^{283}$ It is only when something abrogates the rights that the Constitution grants that the courts should act, and this is the difficulty: what is the substance of those rights to be? There is simply no source that provides easy answers to this question.

How Justice O'Connor's balance between the state and the individual can be measured against Wechsler's neutral principles, then, is difficult. She certainly (indisputably) occupies a ground in every aspect of her jurisprudence that places the focus on the facts of the case and

\footnotetext{
${ }^{282}$ Ibid, p. 19.

${ }^{283}$ Ibid, p. 9.
} 
achieving an answer to the questions asked. The two approaches do not accord well with one another, however. Where Wechsler is encouraging the courts to identify (for example) the freedom to associate and then to apply that principle to the cases within their sphere of influence, Justice O'Connor looked to the cases that came before the Court and determined whether the facts show that the freedom to associate was (to borrow her own language) unduly burdened. She looked primarily to the facts and, in Sunstein's language, measured them against the standards she developed. Wechsler's neutral principles are the broad kinds of answers that O'Connor and other judicial minimalists avoid. They thus seem incompatible.

b. Ely's Theory of Judicial Review

Ely's theory presented in Democracy and Distrust is distilled to its finest essence by the author himself. At its core, Ely says, his is a "representation-reinforcing theory of judicial review."284 He goes on to say that "the general theory is one that bounds judicial review under the Constitution's open-ended provisions by insisting that it can appropriately concern itself only with questions of participation, and not with the substantive merits of the political choice under attack." 285 Ely is as concerned as Wechsler with seeing that judges do not interfere unduly with democracy; he is also as unconvinced as I am that Wechsler's proposals offer more substance than theory. ${ }^{286}$

Ely's theory is also concerned with judicial restraint, but instead of merely acceding to the Constitution's investiture of power to other branches of government, Ely places a greater emphasis on the democratic process itself. In a sense, his theory of judicial review removes judges from the democratic process entirely except for ensuring its smooth functioning. The role

\footnotetext{
${ }^{284}$ Ely, p. 181.

${ }^{285}$ Ibid.

${ }^{286}$ Ibid, pp. 54-55.
} 
of courts, for Ely, is primarily that of protecting participation in the democratic process. ${ }^{287}$ This theory does what he describes above by protecting the political participation and ensuring the representation of all people, including minorities (thus ensuring that they have a voice in the democratic process). Thus, when Ely says that "the approach to constitutional adjudication recommended here is akin to what might be called an "antitrust" as opposed to a "regulatory" orientation to economic affairs - rather than dictate substantive results it intervenes only when the "market," in our case the political system, is systematically malfunctioning." 288 The market (or political system) malfunctions not when results we disagree with come out of the process, but when:
...the process is undeserving of trust, when (1) the ins are choking off the channels of political change to ensure that they will stay in and the outs will stay out, or (2) though no one is actually denied a voice or a vote, representatives beholden to an elective majority are systematically disadvantaging some minority out of simple hostility or a prejudiced refusal to recognize commonalities of interest, and thereby denying that minority the protection afforded other groups by a representative system. ${ }^{289}$

When the system is malfunctioning in these ways, it is appropriate for the courts to use the principles embodied in the Constitution to correct the errors. They do so, as quoted above, regardless of the political choices made by the system - unless those choices show the prejudice and hostility that deny minorities protection.

This unfairly distills Ely's excellent work to a bare-bones minimum, but it should be enough for us to consider whether Justice O'Connor's balance of the state and the individual is compatible with the theory advanced. Certainly, the fit is better. O'Connor's general jurisprudence seems to mesh with Ely's approach in many ways; Sunstein's account of O'Connor's desire to let the democratic process unfold without interference fits nicely here as well. Ely does not speak to the issue of federalism directly, but his argument can be extended to

\footnotetext{
${ }^{287}$ Ibid, pp. 76-77.

${ }^{288}$ Ibid, pp. 102-103.

${ }^{289}$ Ibid, p. 103.
} 
the states quite easily. The question becomes, then: does Ely's account of a participation- and representation-based theory of judicial review mesh with what O'Connor has articulated in her decisions between the state and the individual?

Ely and O'Connor are both concerned with the ability of the individual to participate in the political process. Where they diverge, I argue, is in their scope. In Ely's account, the states provide another level of the democratic process where participation and representation must be ensured, and little more. For O'Connor, they are the very heart - the laboratories - of our democracy, and all that goes with state and local government is critical. The question that Ely asks (is participation and representation protected?) is different than the one that O'Connor asks (is the state able to interfere with political activity and civil life?).

Ely's theory is more complementary to this incremental balance between state and individual than Wechsler's, if only because he offers firmer guidance as to what the courts should look for than Wechsler. His theory, like expressive democracy, encompasses the ability of individuals to participate in government. He is less concerned with their participation in civil society, however, and that is also where I part ways with him (and where I argue that O'Connor does as well). As my analysis of the First Amendment's religious protections and the right to privacy make clear, the courts go beyond simply ensuring protection and representation: they protect civil society as well, as a critical part of the democratic process. 


\section{Conclusion}

At the heart of this discussion is the tension between some of the pillars of our democracy: federalism, majority rule, and the rights of individuals. Framed differently, we might say that we have looked at the debate of when, how, and over whom the different levels of government can exercise control. Justice O'Connor has contributed to this constitutional debate by answering that the states may be able to place reasonable restrictions on the constitutional rights of individuals. This is tempered by the limits she has staked out, recognizing the binding limits the Constitution places on such restrictions. First, they must be broad in their application.

Restrictions that unfairly or unreasonably target only a specific class or group in their exercise of constitutional freedoms are suspect. Second, in line with a general approach of the Supreme Court, any restrictions on individual rights should be narrowly tailored to the asserted state interest. Anything that is overly broad in its application is also suspect.

Taken together, these standards serve two purposes. The first is fundamental to the idea of constitutionalism: the protection of the rights of all individuals in democracy. I have argued that for O'Connor and in the particular context discussed, this took the part of protecting the rights of all individuals to equally participate in civil, political, and economic life wherever possible. As we have seen, for O'Connor, the states are sometimes justified in restricting the freedoms discussed. There exist circumstances where the First Amendment's expressive and religious protections or the right to privacy can be limited. These circumstances, where they exist, are subject to the limits just summarized. O’Connor seems to have had no difficulty finding against states when these boundaries were transgressed, by unfair targeting of groups or 
vague, overbroad statutes. In identifying and enforcing these boundaries, O'Connor went far in helping the Court to help empower individual participation in civil and democratic life.

Just as important as empowering such individual participation, however, was letting the states know where they stood in regard to these rights. As discussed previously, the incorporation of various rights to the states is a relatively recent phenomenon. Incorporating a right, whether freedom of speech, privacy, or the right to bear arms, does not definitively settled the law. O'Connor, an abiding friend of the states, guarded their interests even as she, on occasion, struck them down. Rather than leaving issues of law unsettled, she provided answers to questions of rights that came before the Court. Further, in both the cases we have described and in others as well (Michigan v. Long comes to mind), she often included suggestions for state legislators and judges as to alternatives that the Court may well consider constitutional. As much as she wished to provide the equality of opportunity that allows individuals to be politically and civically active, she also wished to give states the freedom necessary to act as sovereign entities. This balance of interests, I would argue, is precisely what Elazar meant when he said that federalism allows governance while preventing tyranny.

This, then, may be the key to understanding something important about O'Connor's jurisprudence. To understand this, we must first return to Sunstein's logic. First, remember that Sunstein argued that O'Connor sought to develop standards that would, among other effects, allow the democratic process to unfold. Second, remember my own argument that not only did O'Connor seek standards that would further the democratic process but also drove the empowerment of individuals to participate at every level of civil and political life as a critical part of that democratic process. In effect, I argue further, O'Connor's jurisprudence did not seem to have precedential value because of a lack of a judicial philosophy, but rather because 
much of what she sought to accomplish as a judge was directed toward the other branches of government. The former state legislator and state judge never disappeared: on some level, she continued to aim her decisions not only at the constitutional structure of the United States, but also to the other branches of government and to its citizens. Her faith in the democratic process, in the role of the states and of citizens in governance, and the balancing between them she employed may be indicative that her jurisprudence is most useful - and is best understood - in a democratic context.

Casting Justice O'Connor's jurisprudence in this democratic light is the next path for this line of inquiry. I have worked in a very specific context in this text, seeking to demonstrate that O'Connor's devotion to states' rights was tempered by an abiding interest in protecting the constitutional rights that allow individuals to act within civil and political life. By examining her personal and professional backgrounds, a series of opinions written within the areas of expressive, religious, and privacy rights, and the theoretical approaches, both my own and others, I believe that I have demonstrated the ultimate point of this project. Justice O'Connor struck an incremental balance between the rights of states and the individual in our federal system that gave precedent to individual rights, except where restrictions did not "unduly burden" individuals or groups through unfair, unreasonable, or overbroad abuses of power. Future work in this area, I hope, will show that O'Connor's jurisprudence - through the lens of expressive democracy - goes beyond this one now well-trod area. 